$\left(\begin{array}{l}\text { J.Soc.Cosmet.Chem.Jpn. } \\ \text { 詒 } \\ \text { 34 (1) } 25-46-(2000)\end{array}\right.$

香料と香りの特性について

一香料の抗菌性, 抗酸化性と非言語コミュニケーション手段としての香り一*

浅 越 亨
長谷川香料株式会社 フレグランス研究所**

一般的に，匂いは嗅覚で感ずるすべてをさし，香りは心地よい匂いをさす。香りのよし悪しは，その 本来持ちあわせているもののほかに, その人の個人的な体験や文化的な脈絡に多く依存する。一方, 香 料とは狭い意味で, 香料産業が取り扱うものをさすが, 広くは香りをもたらすものをいう。最終商品で の香料使用の主目的は, 当然のことながら, 最終商品の香り付けで, その美的価值を高め, 商品の魅力 を高め, 商品の心地よさを増進させる。これが香料の本来の特性である。その他の香料の特性は，抗菌 性, 抗酸化性, 誘引·忌避性, 消臭性, 心理的作用や生理的作用等であるが, 代表的な機能である抗菌 性と抗酸化性を概説する。微生物の逆襲を受けたり, 日光の害, 酸素の害が明らかになってきた昨今, よ りナチュラルということで香料や香料関連植物の抗菌性や抗酸化性が注目されている。その後で, 香り の特性として, 非言語コミュニケーション手段としての香りの役割について, 文化的な側面から考察す る。ここで, 文化的側面をあえてとりあげるのは, 香料の機能面が重視される昨今, ややもすると, そ れは，香るという本来の機能が二の次になりかねない傾向があるので，香料の命は香りであることを再 認識したいためである。

\section{1.は じめに}

まず，香りと匂いの区別を説明する。一般的に， 匂いは嗅覚で感ずるすべてをさし, 香りは心地よ い匂いをさす。したがって，香りのほうが狭い概 念である。香りのよし悪しは, その本来持ちあわ せているもののほかに，その人の個人的な体験や 文化的な脈絡に多く依存する。よし悪しが生まれ るのも人間だからである。動物は，もっぱら「匂 い」である。動物における匂いの役割はとくに重 要で, その生存から種の繁殖まで関わっている。 人間も, 動物ほどではないが, 匂いあるいは香り は重要である。今回は，人間を中心に考えるので， 香り主体でいく。

* 1999. 12. 2 受理

** 个103-8431 東京都中央区日本橋本町 4-4-14:44-14, Nihonbashi-Honcho, Chuo-ku, Tokyo 1038431, Japan
人間と香りの関わり合いを歴史的にとらえる $と^{1)}$, (1) 食料の鮮度を感知する生命維持機能は基 本として, (2) 魔術的, 呪術的, 宗教的な儀式に 香りを焚き，神秘的なサインを発信し，(3)その 香りが権威の象徵となり, (4)王のパレードや宴 会で香りがまかれたりしたが，これは立派な情報 伝達を目的としたコミュニケーション手段であっ た。また, (5)男女の関わり合いでも, 香りは重 要な役割をはたし，異性を魅了するために香りが 使われた。(2)（5)までの特性を一言でいうと，非 言語（ノンバーバル）コミュニケーション手段と しての機能である。香りによって，言葉を使わず に, 何らかのメッセージの発信と受信を行うので ある。

一方, 香料とは狭い意味で, 香料産業が取り扱 うものをさすが，広くは香りをもたらすものをい う。ここでは, 香りをもたらす植物を含める。最 終商品での香料使用の主目的は，当然のことなが 
ら，その商品の香り付けで，その美的価值を高め, 魅力度を高め, 商品の心地よさを増進させる。香 料が香りをもたらすというとあたり前のことであ るが，これが香料の本来の特性である。その他の 香料の特性は, 抗菌性, 抗酸化性, 誘引·忌避性, 消臭性，心理的作用や生理的作用等であるが，今 回はそのうち, 代表的な機能である抗菌性と抗酸 化性をとりあげる。その後で，香りの特性として， 非言語コミュニケーション手段としての香りの役 割について，文化的な側面から考えてみたい。こ こで，文化的側面をあえてとりあげるのは，香料 の機能面が重視される昨今, ややもすると，それ は，香るという本来の機能が二の次になりかねな い傾向があるので，香料の命は香りであることを 再認識したいためである。

\section{2. 香料の抗菌性}

マーク・N・コーエンの「健康と文明の人類 史」2) は, 人間の歴史は感染症との戦いの歴史で あったことと, 人間と植物の関わり合いが狩猟の 時代から農耕への移行を通じて, 深いものがあっ たことを明らかにしている。世界を変えた植物 ${ }^{3)}$ として, 小麦, 米, ライ麦, トウモロコシなどの 主食のほかに, コショウ, クローブ, シナモン, などの香辛料が重要であった。

冷蔵庫のない時代には, 香辛料が手に入れば, 肉の保存期間を延ばすことができ，腐敗が始まる ころの匂いを消し，味を保てた。コショウ 1 袋と 銀 1 袋の価值が同じとしても理解できる。これは 香辛料の抗菌，抗酸化作用の利用である。15, 16 世紀には香辛料の大航海時代を迎える。コロンブ ス, マジェラン, ドレイク, クックらは命知らず の風雲児たちであった。

Fig. $-1^{4)}$ は 17 世紀中頃のペスト患者に対して診 察に行く医者の姿である。スパイス（シナモン， クローブ）入りの鼻とガラスでカバーされた目を 持つ防毒マスクをしている。そのとき, 室内はセ ージを炊いて消毒したという。

Fig. - $2^{4)}$ は 19 世紀初頭のコレラを予防するため に, スパイスで身を固め, 風車で伝染性の蒸気を 吹き飛ばす婦人の姿である。もちろん, 皮肉を込

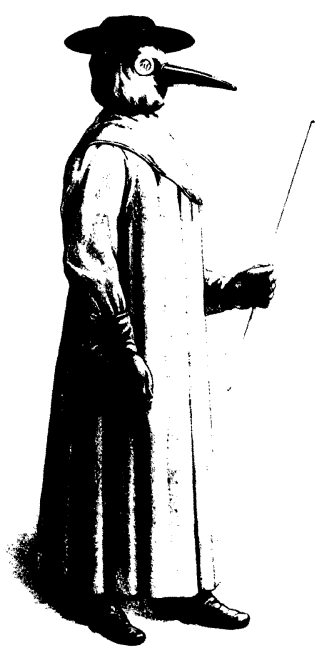

Fig. - 1 Plague-doctor's costume with spice-filled beak (middle $17 \mathrm{C}$ ).

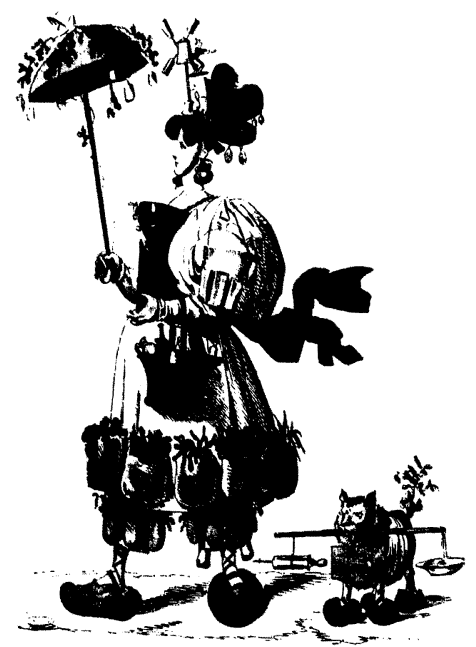

Fig.-2 Lady up against cholera guarded by aromatic herbs and spices (early $19 \mathrm{C}$ ).

めて描いたエッチングであるが，当時の恐怖が十 分伝わってくる。そのスパイスはやはりシナモン とクローブであった。

感染症に関する病原性微生物は人間のわきに そっと寄り添っており，20世紀前半の細菌学の 確立と抗生物質の発見までは，感染症に立ち向か う武器の一つは薬用植物や香辛料であった。 
Table-1 Essential oils tested (trees, shrubs).

\begin{tabular}{|c|c|c|c|}
\hline \multicolumn{2}{|r|}{ 喬木由来精油 } & \multicolumn{2}{|r|}{ 草本 (低木) 由来精油 } \\
\hline $\begin{array}{l}\text { 葉 } \\
\text { 花 }\end{array}$ & $\begin{array}{l}\text { Bay, eucalyptus, cedar, cypress, pimento, 他 } \\
\text { Clove, ylang }\end{array}$ & 全植物 & $\begin{array}{l}\text { Citronella, pennyroyal, lemongrass, rue, pep- } \\
\text { permint, thyme (red, white) }\end{array}$ \\
\hline 果実 & Pimento, nutmeg, lemon, orange, bergamot, & 葉 & Marjoram, clarysage, spearmint, geranium \\
\hline 樹皮 & Cinnamon & 花 & Basil, lavandin, lavender, rosemary, origan- \\
\hline 樹脂 & Benzoin, peru balsam, tolu balsam & & um, 他 \\
\hline 幹 & $\begin{array}{l}\text { Cascarilla, cedar atlas, cedar virginian, sandal- } \\
\text { wood }\end{array}$ & $\begin{array}{l}\text { 種子 } \\
\text { 根茎 }\end{array}$ & $\begin{array}{l}\text { Celery, parsley, angelica, coriander } \\
\text { Vetiver, ginger, 他 }\end{array}$ \\
\hline 根 & Sassafras & & \\
\hline
\end{tabular}

\section{1. 植物からみた抗菌性}

香料の抗菌性は, 植物の抗菌性といっても差し 支えないが，植物の抗菌性に関しては，フィトア レキシンや医薬品開発を含めた山野の優れた総説 がある ${ }^{5), 6)}$ ので, ここでは, 植物からみた香料 (香 り）の抗菌性を紹介する。それは, Blakeway)の 仕事である。

香料関連植物の抗菌性は, 植物そのものの大き さ(喬木, 低木, 草本) や, それぞれの部位 (葉, 花, 果実, 種子, 樹皮, 樹脂, 幹, 根茎等) で異 なる。Blakeway ${ }^{7)}$ は, Table-1の喬木からのそれ ぞれの部位由来の精油 22 種, 草本 (低木) から は28種の天然精油類について, Table-2の細菌 類 (6 種のグラム陰性菌, 2 種のグラム陽性菌) 々真菌類（6 種の酵母，8種のカビ類）に対する 抗微生物試験を行っている。ここで，表記した微 生物は, 化粧品污染を起こす主なもので8), 今回 の香料の抗菌性はこれらを中心話を進める。

ただし，Table-1の喬木由来の精油にはいくつ かの低木が含まれ, Table-2の草本(低木)からの 精油はほとんどが草本由来である。結果を Fig. 3， 5 に示す。ここでいう有効率とは試験したも ののなかでの有効なものの比率である。有効率が 高ければ，その植物部位由来の精油が有効である 比率が高いということである。Fig. $-4 ， 6$ には平 均活性度 (平均阻止円) を示すが，それから抗菌 力がわかる。

非常に興味深いことは，ほとんどの精油が空気 伝染性の胞子を形成するBacillus subtilis（枯草 菌）や酵母，カビに抗菌性があることである。こ
Table-2 Microorganisms tested.

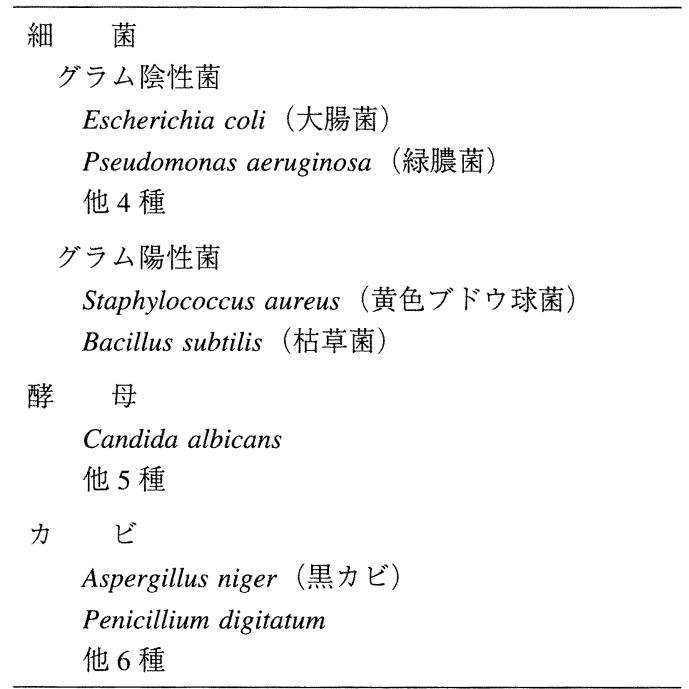
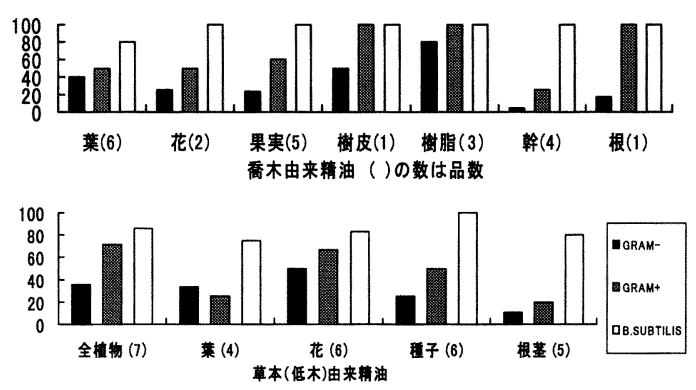

Fig. -3 Percentage of essential oils showing antibacterial activity (\%) in trees and shrubs.

れは抗菌性が弱いと植物としての存在に関わるか らである。そして, 樹幹木部の精油に活性が少な く，樹皮の精油や樹皮を傷つけたときに分泌され 

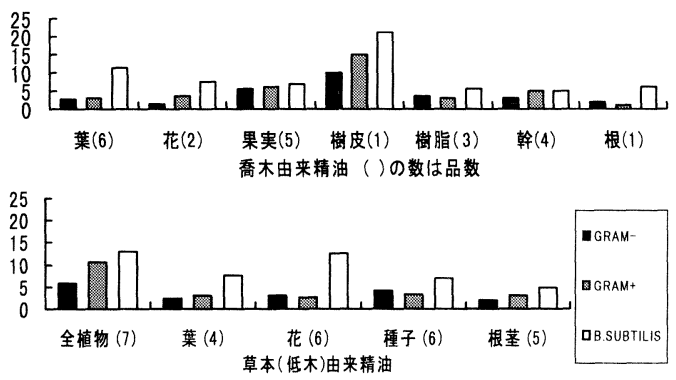

Fig. - 4 Mean antibacterial activity of essential oils $(\mathrm{mm})$ in trees and shrubs.
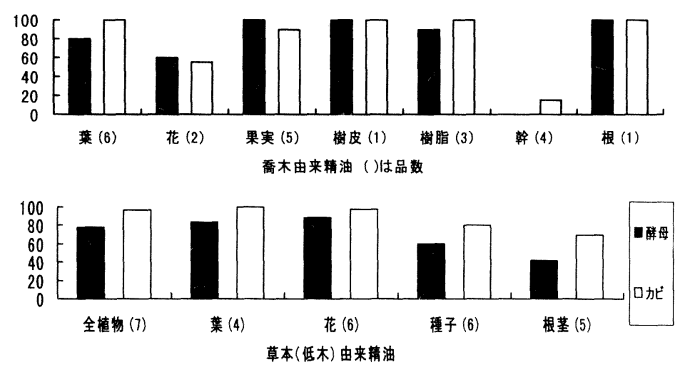

Fig. -5 Percentage of essential oils showing antifungal activity (\%) in trees and shrubs.

る樹脂は抗菌性が高いことも面白いところで，植 物としての当然の成り立ちを示唆している。樹幹 木部の不活性さは樹皮に保護されているところか らくる不必要と説明されている。また, 草本由来
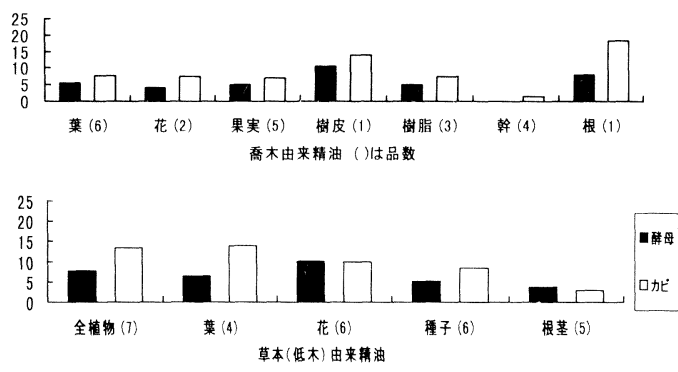

Fig. -6 Mean antifungal activity of essential oils $(\mathrm{mm})$ in trees and shrubs.

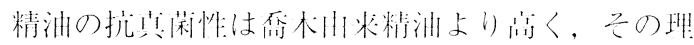
由として，苦本のおが微性物の攻慗が多いからで あろうとしている。

\section{2. 天然精油の抗菌, 抗真菌性}

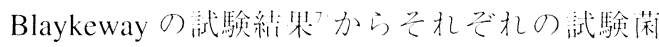
の阻止归を全胴したものが，Fig.-7，8である。 抗莉性の宫い精油は eucalyptus, cinnamon. bergamot, tolu balsam (否木, 低标), thyme red, thyme white, rue (特にStaphylococcus aureus に们效) (薄

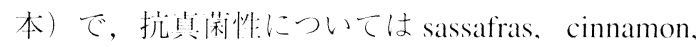
pimento, tolu balsam (甭本), origanum, thyme red. lemongrass, basil, coriander, spearmint (菅本) 等が 份效である。巟に触れたが，蓝本州米の大然精洲 の抗真藏性が落いことがわかる。

香料素材の抗藏，抗息菻性を系統的に淍べたの は, Maruzzella et al.”・である。彼らは南接的

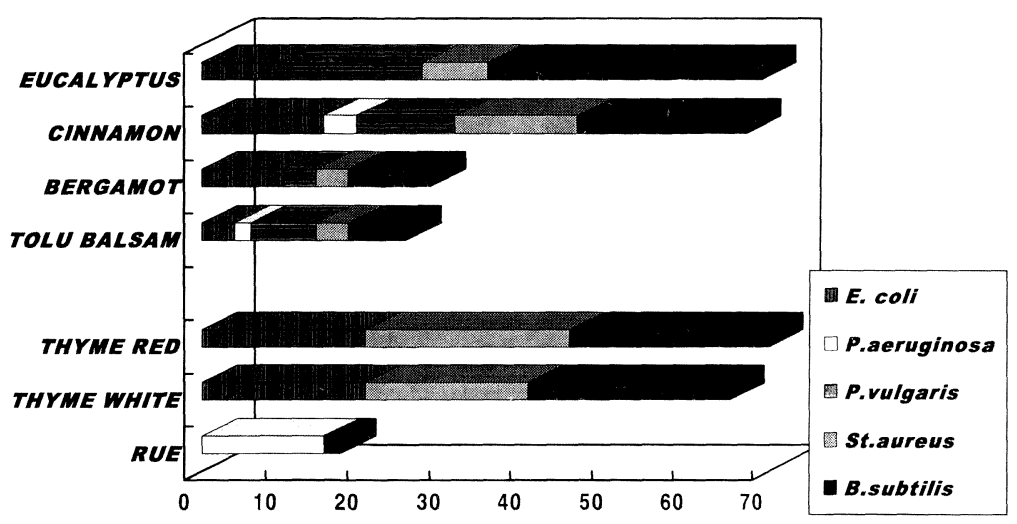

阻止丹 $(\mathrm{mm})$

Fig. -7 Antibacterial essential oils (by Blakeway? ). 


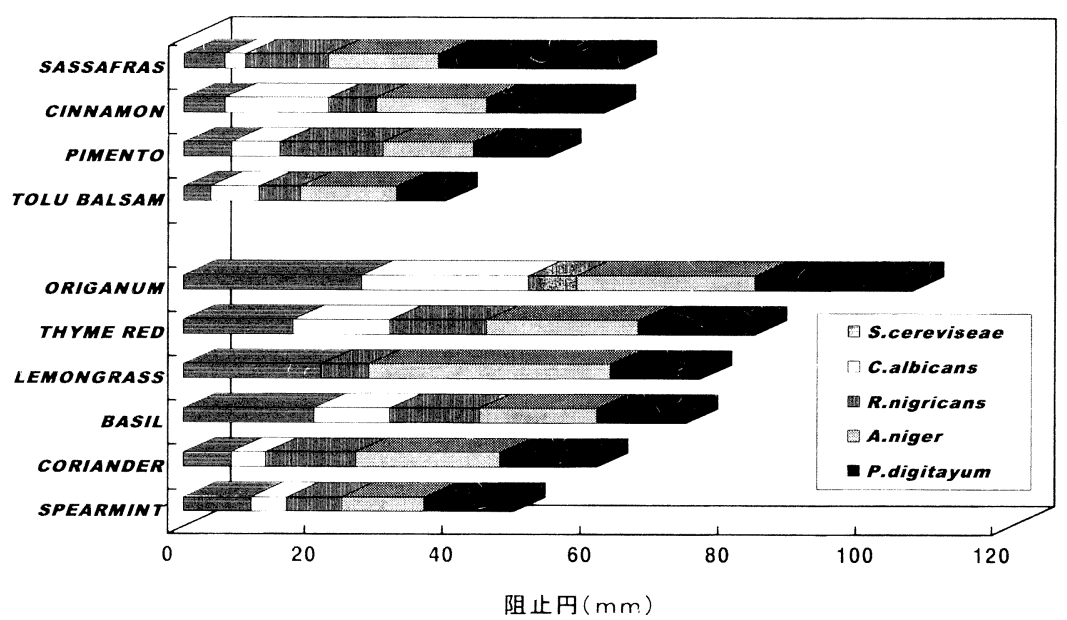

Fig. - 8 Antifungal essential oils (by Blateway? ).

Table-3 Antibacterial essential oils (by Marmellit").

\begin{tabular}{|c|c|c|c|}
\hline \multicolumn{2}{|c|}{ 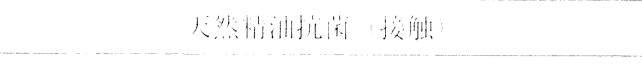 } & \multicolumn{2}{|c|}{ 人然䊑洲扰闲（Vapor） } \\
\hline 质效涪 & $\begin{array}{c}100110 \text { 粘洋 } \\
\left.(90.9)_{0}\right)\end{array}$ & 们㸚摔 & $\begin{array}{l}\text { 179) } 784 \text { 䊑沙 } \\
22.8 \%)\end{array}$ \\
\hline 份效梢洲 & 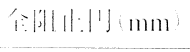 & 们刘粗洲 & ||$_{1}^{\prime}|1| \cdot 1 \mathrm{l}(\mathrm{mm})$ \\
\hline Eucal!ptus & 83 & Thyme red & $25-57$ \\
\hline Birch titr & 78 & Thyme white & $2(0-51$ \\
\hline Cimnamon & $6+$ & Calssia & $19-60$ \\
\hline Toru balsim & 40 & Silvory & $17-68$ \\
\hline Cedar lealf & to & Cimnamon & $20-54$ \\
\hline Thyme & 36 & Lemongrass & $(0-90$ \\
\hline Penmyroyal & 33 & Cherry laturel & $(0-90$ \\
\hline Cumin & 32 & & \\
\hline l.arender & 30 & & \\
\hline Passley seed & 30 & & \\
\hline 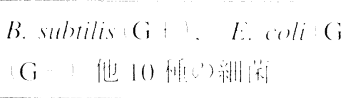 & acrusinesa & 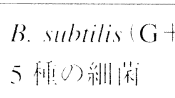 & e'us $(G-)$ ) 他 \\
\hline
\end{tabular}

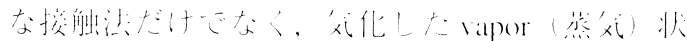

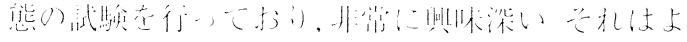

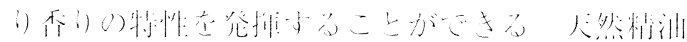

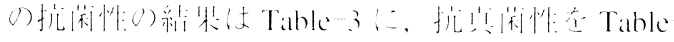
十沶小多

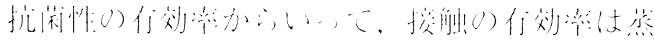

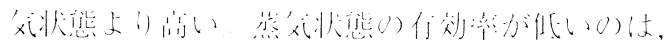

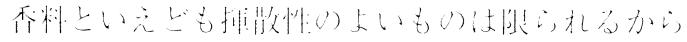

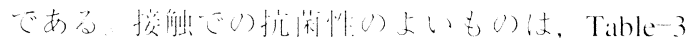

ー゙リリらかであるが, eucalyptus, birch tar, cinnamon, tolu balsam. cedar leaf, 蕉独状掏では thyme red, thyme white, cassia, savory, cinnamon 管である。

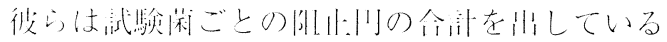

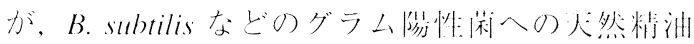

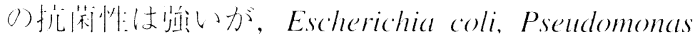
aruginosa などのグラム䧔性闲に刘しては蛰い。 こ机は他にもいえる・般们な倾们である。卒考 までに，E. coli上P. a ruginosaに们效な(接触) 
Table-4 Antifungal essential oils (by Maruzzella'" ).

\begin{tabular}{|c|c|c|c|}
\hline \multicolumn{2}{|c|}{ 天然精油抗真菌性（接触） } & \multicolumn{2}{|c|}{ 人然精洲抗员莉性（Vapor） } \\
\hline 有効率 & $\begin{array}{c}90 / 92 \text { 精油 } \\
(97.8 \%)\end{array}$ & 有效率 & $\begin{array}{c}114136 \text { 精油 } \\
(83.8 \%)\end{array}$ \\
\hline 有効精油 & 全阴止川 $(\mathrm{mm})$ & 们效精油 & lith: $\left.\left.\left.1\right|^{1}\right|^{1}\right\}(\mathrm{mm})$ \\
\hline Origanum red & 318 & Cumin & $90-90$ \\
\hline Lemongrass & 275 & Eucalyptus & $4(0-90$ \\
\hline Thyme red & 269 & Tarragon & $25-90$ \\
\hline Birch sweet & 244 & Birch sweet & $25-90$ \\
\hline Savory & 241 & Spearmint & $4(0-9()$ \\
\hline Coriander & 208 & Caraway & $25-90$ \\
\hline Sassafras & 202 & Basil sweet & $35-90$ \\
\hline Cinnamon & 192 & & \\
\hline Laurel leaves & 172 & & \\
\hline Spearmint & 162 & & \\
\hline
\end{tabular}

Aspergillus niger, Candida albicans, Penicillium digitatum 他 15 種の酵母, カビ
Rhizopus nigricans, Saccharomyces cereviseae, Can-

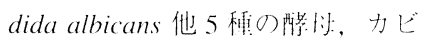

精油を特記すると, cedar leaf, birch tar, thyme ( $E$. coli), rue, birch tar (P. aeruginosa) などである。

\section{蒸気状態での抗菌性のよい精油の揮散成分は,} thyme, savory が thymol, carvacrol で, cassia, cinnamonは cinnamic aldehyde, lemongrass は citral であ る。これらは香辛料である。前述の17〜19 世紀 の人々が香辛料を身につけて感染症（黑死病, コ レラ）と闘ったのも，この抗菌作用を期待したか
らである。

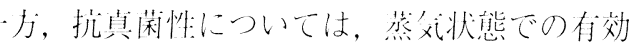
率がかなり槀い。人然精沺ばかりでなく，否料一

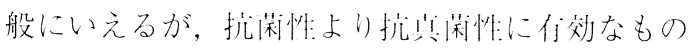

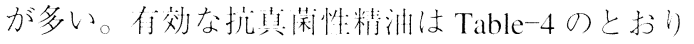
である。蒸知状態で抗思藏性のよい大然精油の揮 散成分をあげると, cumin は cumin aldehyde, eucalyptusは1,8-cineole, tarragon は methyl chavicol,

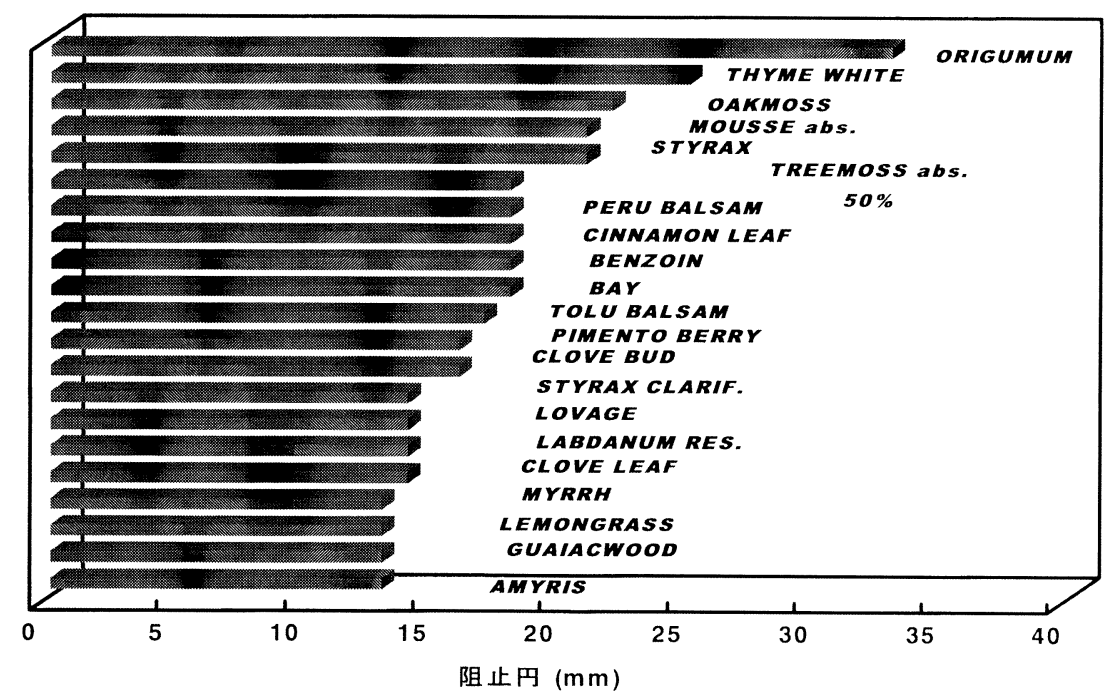

Fig. - 9 Antibacterial essential oils against S. aureus. 


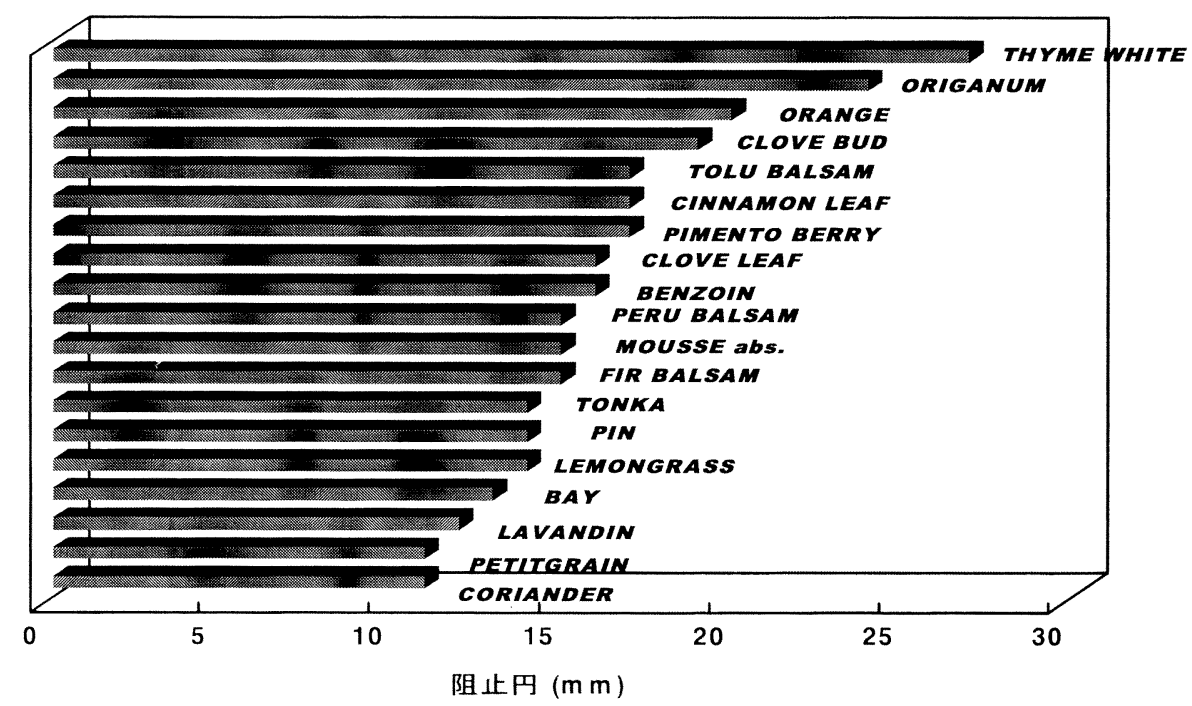

Fig. -10 Antibacterial essential oils against E. coli.

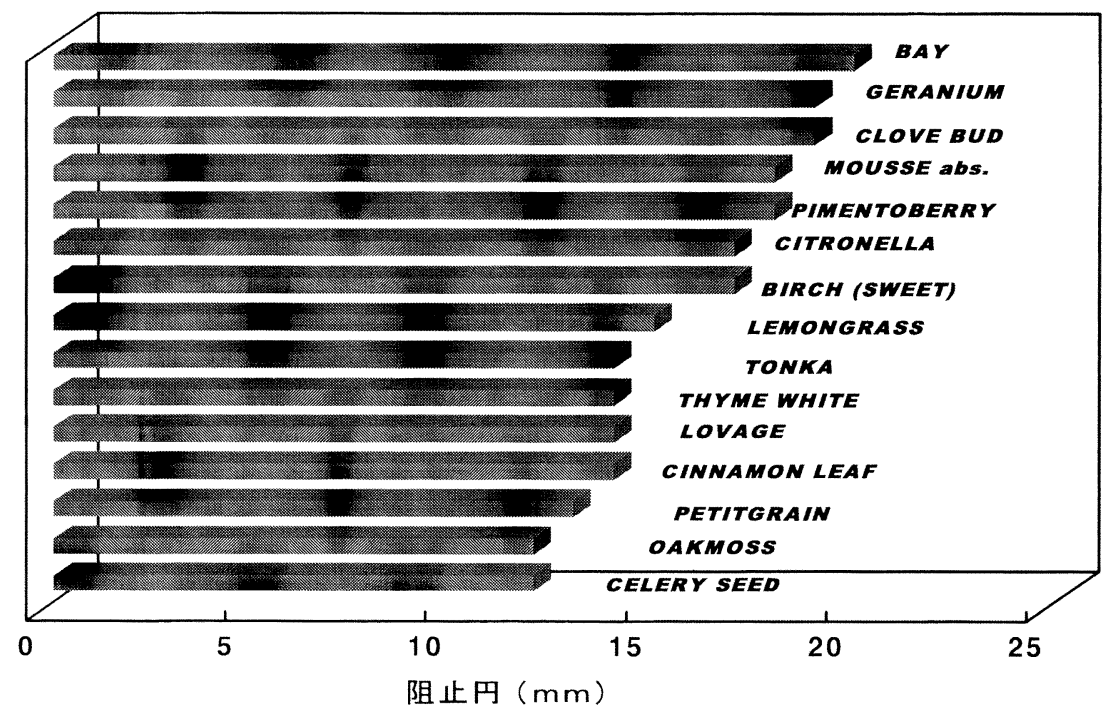

Fig. -11 Antibacterial essential oils against Candida albicans (mm).

birch sweet は methyl salicylate, spearmint は $/$-carvone, caraway はd-carvone, basil sweet は methyl chavicol, eugenol だある

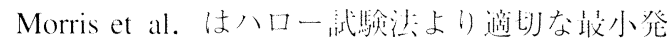

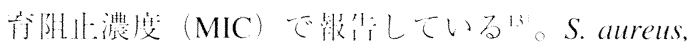

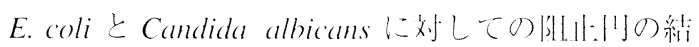

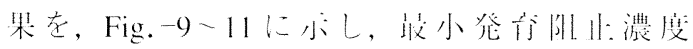
(MIC) の維粕在, Table-5一
MICの結果から，S. aureus に対して mousse abs. oakmoss, sandalwood, treemoss abs.などが有効で, E. coliには, basil, fennel sweet, lemongrass, origanum, thyme white などである。C. albicansに対し ては opoponaxが有効であり, 興味深いところで ある。

しかしながら，MICを比較すれば明らかなよ うに, Morrisの結果は天然精油の効果がトリクロ 
Table-5 MIC of antibacterial essential oils against S. aureus.

\begin{tabular}{lc}
\hline & MIC (ppm) \\
\hline Mousse abs. & 50 \\
Oakmoss & 50 \\
Sandalwood & 50 \\
Treemoss abs. 50\% & 100 \\
Basil & 500 \\
Bay & 500 \\
Caraway & 500 \\
Cinnamon leaf & 500 \\
Clove bud & 500 \\
Clove leaf & 500 \\
Cumin & 500 \\
Fennel (sweet) & 500 \\
Fir balsam & 500 \\
Grapefruit & 500 \\
Guaiacwood & 500 \\
Labdanum resin & 500 \\
Lemon & 500 \\
Lemongrass & 500 \\
Nutmeg & 500 \\
Orange & 500 \\
Origanum & 500 \\
Patchouli light & 500 \\
Pimentoberry & 500 \\
Pineneedle & 500 \\
Sauge sclaree & 500 \\
Tangerine & 500 \\
Thuja & 500 \\
\hline TCC & 500 \\
\hline
\end{tabular}

Table- 6 MIC of antibacterial essential oils against E. coli.

\begin{tabular}{lr}
\hline & MIC $(\mathrm{ppm})$ \\
\hline Basil & 500 \\
Fennel (sweet) & 500 \\
Lemongrass & 500 \\
Origanum & 500 \\
Thyme white & 500 \\
\hline TCC & 200 以. \\
Triclosan & 0.06 \\
\hline
\end{tabular}

サンや TCCなどの令成の殺藏剂に比べるとは は るかに弱いこと走小している。否料の限界といえ ば、いえなくはない。

ここで香料の挽明在するが, abs.とはアブソ リュートといい，溶剂抽怕によって得ら机る夫然 精油のことである。もつと川碓にいうと，们湔工 一テルやへキサンなどの浫剂で抽してコンクリ

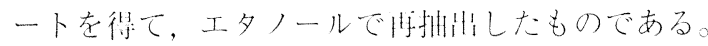
ここでの mousse abs.は oakmoss abs.のことであ るが, treemoss abs. も会めて, 潎の木やマツ科の 樹木に算生する地衣類のアブソリュートである。 アブソリュートは一般的には花肼枨の花精油, た とえば roseやjasminのアブソリュートのことを

Table-7 MIC of antibacterial essential oils against C. albicans.

\begin{tabular}{lc}
\hline & MIC $(\mathrm{ppm})$ \\
\hline Opoponax & 50 \\
Basil & 500 \\
Bergamot & 500 \\
Caraway & 500 \\
Chamomile & 500 \\
Cinnamon leaf & 500 \\
Clove bud & 500 \\
Clove leaf & 500 \\
Cumin & 500 \\
Fennel (sweet) & 500 \\
Grapefruit & 500 \\
Lemon & 500 \\
Lemongrass & 500 \\
Lime & 500 \\
Mandarin & 500 \\
Mousse abs. & 500 \\
Orange & 500 \\
Origanum & 500 \\
Petitgrain & 500 \\
Pimentoberry & 500 \\
Pine & 500 \\
Spearmint & 500 \\
Thyrax & 500 \\
Wintergreen & 500 \\
\hline TCC & 500 \\
\hline & 100 \\
Triclosan & 6 \\
\hline
\end{tabular}


いうのである。また，とくに、ことわりのない塌

苓, 古なわち oakmoss, basil, fennel sweet, lemongrassなどは才イルのことである。才イルとは水 蒸爻筧留に上って得ら机た大然粗洲のことであり,

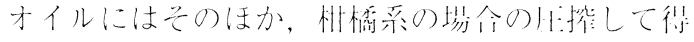

られた天然精油をも含む。

Sawano et al.の MIC の評価によれば(4), S. aureusには, sandalwood, vetiver, treemoss abs., oakmoos abs., clary sagae abs., thyme, pimento, lemongrass, labdanum abs., clove, bay, amyris 等, E. coli

Table-8 Antibacterial essential oils (direct and vapor contact).

\begin{tabular}{|c|c|c|c|c|c|c|c|c|}
\hline \multirow{3}{*}{ Essential oil } & \multicolumn{4}{|c|}{ B. subtilis } & \multicolumn{4}{|c|}{ E. coli } \\
\hline & \multicolumn{2}{|c|}{$\begin{array}{l}\text { Direct } \\
\text { contact }\end{array}$} & \multicolumn{2}{|c|}{$\begin{array}{l}\text { Vapor } \\
\text { state }\end{array}$} & \multicolumn{2}{|c|}{$\begin{array}{l}\text { Direct } \\
\text { contact }\end{array}$} & \multicolumn{2}{|c|}{$\begin{array}{l}\text { Vapor } \\
\text { state }\end{array}$} \\
\hline & $\mathrm{DCZ}(\mathrm{mm})$ & DGI & $\mathrm{DCZ}(\mathrm{mm})$ & DGI & $\mathrm{DCZ}(\mathrm{mm})$ & DGI & $\mathrm{DCZ}(\mathrm{mm})$ & DGI \\
\hline Anis star oil & 9 & H & () & + & 12 & + & 0 & - \\
\hline Aromise oil & 18 & $H$ & () & - & 16 & - & 0 & - \\
\hline Bergamot oil & 13 & - & () & - & 9 & - & 0 & - \\
\hline Cade oil R & 20 & - & () & - & 0 & - & 0 & - \\
\hline Calamus oil & 10 & & () & - & 10 & - & () & - \\
\hline Camomille blue oil & 10 & - & () & - & 0 & - & 0 & - \\
\hline $\begin{array}{l}\text { Camomille ramaine } \\
\text { oil }\end{array}$ & 15 & & () & - & 18 & - & 0 & - \\
\hline Cedar leat oil & 15 & $H$ & () & + & 16 & H & 0 & - \\
\hline Cedar wood oil & 10 & - & () & - & 0 & - & 0 & - \\
\hline Citronella oil & 80 & & 80 & & 20 & $H$ & 0 & - \\
\hline Clove bud oil & 21 & - & () & - & 16 & - & 0 & - \\
\hline Galvanum oil & 9 & - & () & - & 0 & - & 0 & - \\
\hline Hiba oil & 12 & H & () & - & 0 & - & 0 & - \\
\hline Hinoki oil & () & & () & - & 0 & - & 0 & - \\
\hline Hop oil & () & - & () & - & () & - & 0 & - \\
\hline Lavender oil & 13 & H & () & + & 14 & + & 0 & - \\
\hline Lemon oil & 10 & - & 0 & - & 14 & + & 0 & - \\
\hline Lemongrass oil & 8() & & 80 & & 24 & H & 0 & - \\
\hline Lime oil & 17 & - & () & - & 20 & + & 0 & - \\
\hline Nutmeg oil & 9 & - & () & - & 12 & + & 0 & - \\
\hline Peppermint oil & 15 & $H$ & () & - & 20 & $H$ & () & - \\
\hline Petigrain oil & 21 & H & () & $H$ & 17 & - & 0 & - \\
\hline Pine oil & 13 & - & () & - & 14 & - & 0 & - \\
\hline Pineneedle oil & 10 & H & () & + & 10 & + & 0 & - \\
\hline Rosemary oil & 10 & H & () & + & 12 & + & 0 & - \\
\hline Sage clary oil & 10 & $H$ & () & - & 0 & - & 0 & - \\
\hline Sage spanish oil & 15 & H & () & H & 23 & H & 0 & - \\
\hline Terpenetine oil & 10 & - & () & + & 10 & - & 0 & - \\
\hline Thyme red oil & 34 & H & 21 & H & 26 & H & 21 & H \\
\hline Vetiver oil & 0 & - & () & - & 0 & - & 0 & - \\
\hline Phenol (10 mg ) & 27 & $H$ & 20 & $H$ & 20 & $H$ & 0 & + \\
\hline
\end{tabular}

DCZ: the diameter of the clear zone. DGI : the degree of the growth inhibition on the plate except the clear rone. - : no inhibition, + : week inhibition, 4 : strong inhibition. 
Table- 9 Antibacterial aromachemicals (by Marurzellat $\left.\right|^{\mid 8.10}$

\begin{tabular}{|c|c|c|c|}
\hline \multicolumn{2}{|c|}{ 合成香料抗菌（接触） } & \multicolumn{2}{|c|}{ 令成夜料抗藏 (Vapor) } \\
\hline 有效率 & $\begin{array}{c}186 / 230 \text { 精浀 } \\
(80 \%)\end{array}$ & 住㸚率 & $\begin{array}{c}167192 \text { 䊑油 } \\
(87 \%)\end{array}$ \\
\hline 有効合成香料 & 発育阴归: 希釈倍数 & 们效令成秀料 & 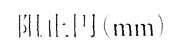 \\
\hline C-8 alcohol & $10000-500$ & C-7 aldehyde & 90 \\
\hline C-10 alcohol & $10000-500$ & C-9 aldehyde & $45-90$ \\
\hline C-11 (:) aldehyde & $10000-1000$ & Isoamyl formate & 9() \\
\hline Benzaldehyde & $2000-1000$ & n-Butyl propionate & 90 \\
\hline Cinnamic aldehyde & $10000-500$ & Ethyl propionate & 9() \\
\hline Methyl heptine carbonate & $10000-500$ & Heptyl formate & 90 \\
\hline Ethyl phenyl acetate & $2000-500$ & Methyl heptenone & $4(0-90$ \\
\hline Eugenol & $10000-500$ & C-7 alcohol & $4(0-90$ \\
\hline Methyl acetophenone & 1000 & Isovaleric acid & $50-60$ \\
\hline Heptoic acid & $2000-500$ & & \\
\hline \multicolumn{2}{|c|}{$\begin{array}{l}\text { B. subtilis, S. aureus }(\mathrm{G}+), E . c o l i(\mathrm{G}-) \text {, 他 } 4 \text { 程の絒 } \\
\text { 菌 }\end{array}$} & \multicolumn{2}{|c|}{$\begin{array}{l}\text { B. subtilis }(\mathrm{G}+) \text {. S. aureus }(\mathrm{G}+) \text {. E. coli }(\mathrm{G}-) \text {, } \\
\text { 他 } 5 \text { 和の綝莉 }\end{array}$} \\
\hline
\end{tabular}

には, thyme, clove が有効である。

Yoshikawa and Mihara ${ }^{15)}$ よよれ゙, allspice oleoresin, bay, clove, oakmoss abs., pimento, thyme red である。これらはプロピル, ブチルパラベンと间 程度の抗菌力である。oleoresin（オレオレジン） とはアセトンなどの揮発性溶剂で抽出した香味と 呈味を含んだ食品用の抽出物である。

そのほか, Gochou ${ }^{(6)}$ ，西村 ${ }^{17\rangle}$ の報告がある。Gochouの天然精油の結果は, Table-8に示古。

\section{3. 合成香料の抗菌, 抗真菌性}

Maruzzellaによれば(8).19)，合成香料の接触によ る抗菌性の有効率は $80 \%$, 蒸気状態での抗菌性 有効率は $87 \%$ である。蒸気状態で高いのは, 揮 散性の高い aldehyde や esterに頁うものである。 結果は, Table-9のと扮りである。接触で抗菌性 のよかったものは C-8 alcohol, C-10 alcohol, C-11 (:) aldehyde, benzaldehyde, cinnamic aldehyde, methylheptine carbonate, ethyl phenyl acetate, eugenol 等で あり, 蒸気状態では C-7 aldehyde, C-9 aldehyde, isoamyl formate, $n$-butylpropionate, ethyl propionate 等である。

官能基による抗菌性の傾向を抗菌有效率でみて いくと, 接触の場合は aldehyde $(24 \%), \operatorname{alcohol}(22$
Table-10 Chemical structure and antibacterial activity.

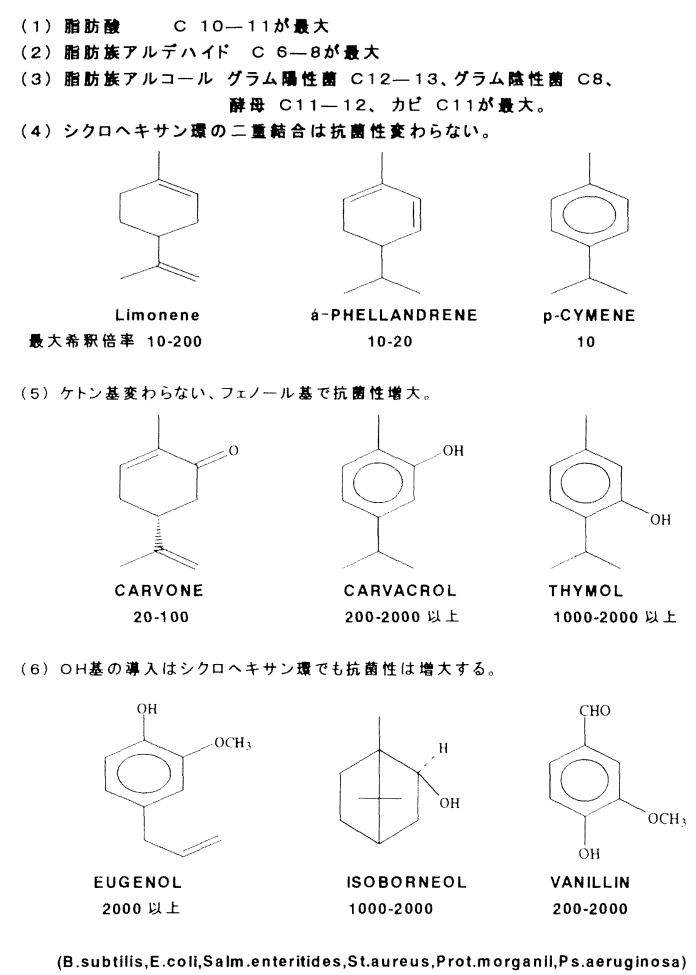


$\%)$, acid $(15 \%)$, lactone $(14 \%)$, ether $(7 \%)$, ke-

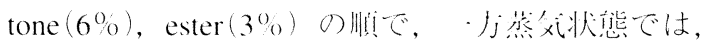
$\operatorname{acid}(100 \%)$, aldehyde $(65 \%)$, ketone $(58 \%)$, alcohol $(56 \%)$, ester $(42 \%)$, ether $(40 \%)$, acetal

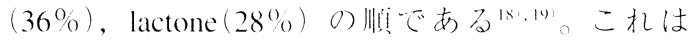
1 例であるが，倾问は十分つかめる。また，Maru

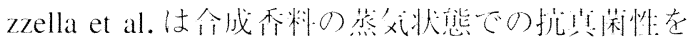
赤等している゙。
合成香料の抗真菌性に関して，栗田 ${ }^{21}$ は alcohol 類の抗真菌性を報告している。1-nonanol, 1-decanol, geraniol, citronellol の抗真菌性は高く，第二，第 級アルコール（たとえば linalool, terpineol）よ り宫い。親水性のアルコール (1-hexanol, benzyl alcohol）は抗真菌性が低く，ある程度の疎水性が 必装である。菌体の疎水部分との相互作用が重要 で，紐胞膜の脂質性によりある程度の疎水性が必

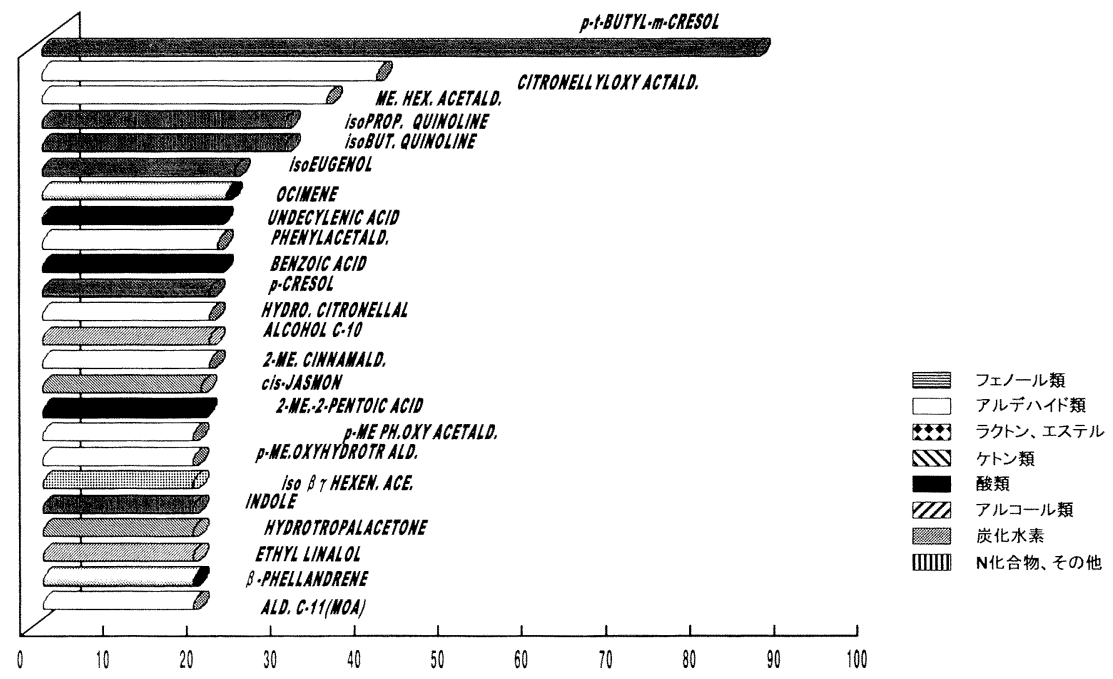

Fig. -12 Antibacterial aroma chemicals against S. aureus (mm).

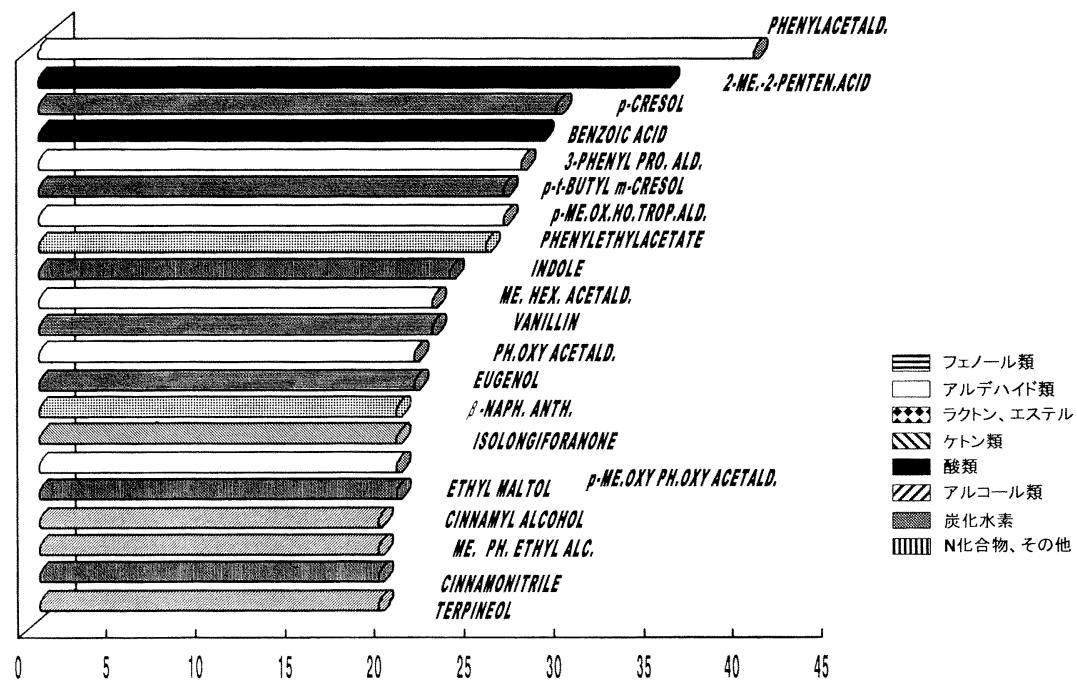

Fig. -13 Antibacterial aroma chemicals against E. coli (mm). 
要なのである。抗菌性の作用機構としては，ほに アルコール，フェノール，有機睖等によるる緗胞朕 攪乱作用とアルデヒド類による細胞内の求核门能 基への反応で，生命活動に必要な陼素や基質を不 活性化することである22.23。化学構虺と抗莉性の 関係を Table-10 に示す2+.25)。

Morris et al.の合成香料のデー夕を们能基で衣

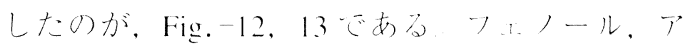

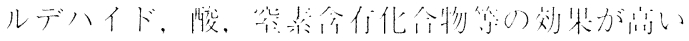
ことがオかる

その他のデータとしては、Morris". Sawano ${ }^{1+}$.

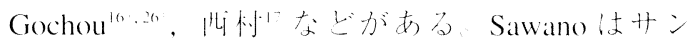

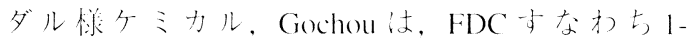
formyl-3,5-dimethyl-3-cyclohexene 0 扰洋性:につい

Table-11 Antibacterial aroma chemicals (direct and vapor contact).

\begin{tabular}{|c|c|c|c|c|c|c|c|c|}
\hline \multirow{3}{*}{ Aroma chemical } & \multicolumn{4}{|c|}{ B. subtilis } & \multicolumn{4}{|c|}{ E. coli } \\
\hline & \multicolumn{2}{|c|}{$\begin{array}{l}\text { Direct } \\
\text { contact }\end{array}$} & \multicolumn{2}{|c|}{$\begin{array}{l}\text { Vapor } \\
\text { state }\end{array}$} & \multicolumn{2}{|c|}{$\begin{array}{l}\text { Direct } \\
\text { contact }\end{array}$} & \multicolumn{2}{|c|}{$\begin{array}{l}\text { Vapor } \\
\text { state }\end{array}$} \\
\hline & $\mathrm{DCZ}(\mathrm{mm})$ & DGI & $\mathrm{DCZ}(\mathrm{mm})$ & DGI & $\mathrm{DCZ}(\mathrm{mm})$ & DGI & DC7 $(\mathrm{mm})$ & DGl \\
\hline Acetaldehyde & 0 & - & () & - & () & & () & \\
\hline Bomyl acetate & 13 & H & () & & () & & () & \\
\hline l-Carvon & 12 & - & () & - & 13 & + & 0 & - \\
\hline Cedrene & 10 & - & () & - & () & & () & - \\
\hline Cineol & 10 & - & () & & 1.3 & - & () & \\
\hline Cinnamic aldehyde & 28 & - & () & - & 25 & $1+$ & () & \\
\hline Citral & 40 & H & () & & 20 & & () & \\
\hline Eugenol & 22 & - & () & & 18 & t & () & - \\
\hline $\begin{array}{l}\text { 1-Formyl-3,5-dimethyl 3- } \\
\text { cyclohexene }\end{array}$ & 80 & & 80 & & 80 & & 80 & \\
\hline $\begin{array}{l}\text { 1-Formyl-3,6-dimethyl 3- } \\
\text { cyclohexene }\end{array}$ & 80 & & 80 & & 80 & & 80 & \\
\hline Geranonitrile & 12 & - & () & - & 25 & & () & \\
\hline cis-3-Hexenol & 10 & - & () & - & 1.3 & & () & \\
\hline Heptyl aldehyde & 80 & & 8() & & 8() & & $s()$ & \\
\hline Hydratropic aldehyde & 45 & it & () & tt & 20 & & 20 & + \\
\hline Isoamyl acetate & () & - & 0 & - & () & & () & \\
\hline Isoamyl formate & 0 & - & () & - & () & & () & \\
\hline Isobomyl acetate & 18 & - & 0 & - & () & & () & \\
\hline Isocyclo citral & 80 & & 80 & & () & & 0 & \\
\hline Isosafranal & 37 & H & 0 & H & () & H & () & \\
\hline Limonene & 10 & - & () & - & 10 & + & () & \\
\hline Methyl salicylate & 12 & it & () & 11 & 17 & & () & - \\
\hline Nonyl aldehyde & 80 & & 80 & & 80 & & 80 & \\
\hline Para aldehyde & 10 & - & () & - & 20 & & () & \\
\hline Phellandrene & 10 & - & () & - & 13 & + & () & \\
\hline$\beta$-Pinene & 0 & - & () & & 18 & + & () & \\
\hline 3,5,5-Trimethyl cyclohexanol & 16 & + & () & & 20) & & () & \\
\hline 3,5,5-Trimethylhexanol & 20 & $H$ & () & + & 20 & - & () & - \\
\hline Phenol $(10 \mathrm{mg})$ & 27 & $H$ & 20 & $H$ & 20 & $H$ & () & + \\
\hline
\end{tabular}

DCZ: the diameter of the clear zone. DGI : the degree of the growth inhibition on the plate except the clear zone. - : no inhibition, + : week inhibition. $+t$ : strong inhibition. 


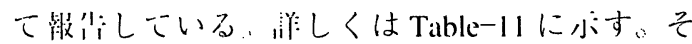

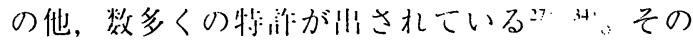

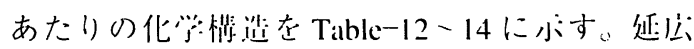

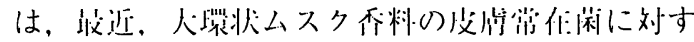

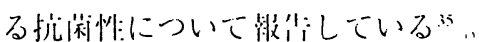

\section{4. 蒸気状態の抗菌性}

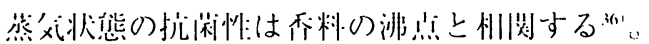

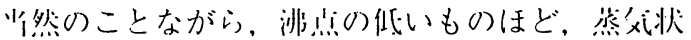

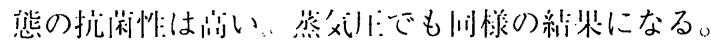

\section{5. 香料の安全性と安定性の問題}

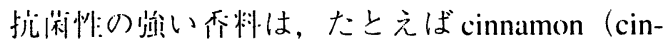
namic ald.)， clove(eugenol)などのように、特微啲

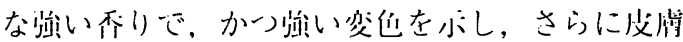

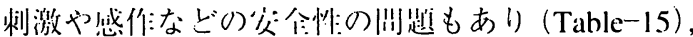

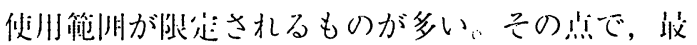

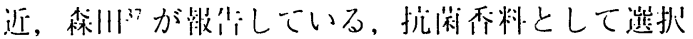
された lavender, rosemary, coriander, pineneedle, aspic lavender. terpineol, citronellol, clove(少保使朋),

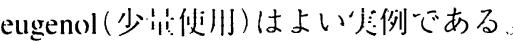

Table-12 Antibacterial antifungal perfume (1).<smiles>Cc1ccc(C(C)C)c(O)c1</smiles>

THMMOL CARNACROL (THMME, SAVOFM

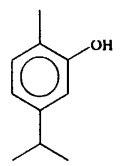

CNNAMIC ALDEHDE (CASSIA) (H) OH $\mathrm{OCH}_{3}$ il

CINNAMC ALDEHYDE EUGENOL (CNNAMON) CHO CHO<smiles>C=CC</smiles>

CHO<smiles>CC12CCC(CC1)C(C)(C)O2</smiles>

1,8-CNEOL (EUCALYPTUS)<smiles>C=CCc1ccc(OC)cc1</smiles>

CTRAL (LEMONGRASS

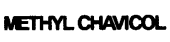
(TARRAGON)
Table-13 Antibacterial antifungal perfume (2).<smiles>CCc1ccc(C(C)C)cc1</smiles>

CUMIN ALDEHYDE (CUMIN)<smiles>COC(=O)c1ccccc1O</smiles>

METHYL SALICYLATE (BIRCH SWEET)

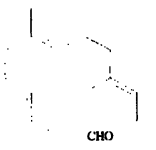

FARNESAL （特公告 回 59-45646）<smiles>C=CCc1ccc(O)c(O)c1</smiles><smiles>C=CCc1ccc(CC)cc1</smiles>

EUGENOL ( BASIL SWEET )<smiles>C=C(C)[C@H]1CC=C(C)C(=O)C1</smiles>

I-CARVONE ( SPEARMINT)

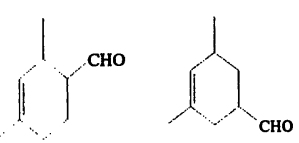

1-FORMYL-3,5-DIMETHYL-3CYCLOHEXENE (FCC) (特公告 平 3-77161)
Table-14 Antibacterial antifungal perfume (3).<smiles>CCC(C)(O)CCCC(C)C</smiles><smiles>C=CC(C)(O)CCCC(C)C</smiles><smiles>CC(C)=CCCC(C)=CC=O</smiles>

TETRAHYDROUNALOOL DEHYDROLINALOOL

CITRAL

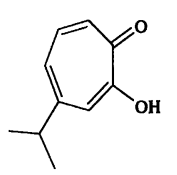<smiles>c1ccc2c(c1)OCO2</smiles>

CHO

HINOKMTLL

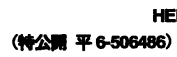<smiles>O=CC=Cc1ccccc1</smiles>

VANILLIN
CINNAMIC ALDEHYDE (特公闲 回 59-140868） 


\section{6. 抗微生物性調合香料の例}

抗菌性調合香料と防力ビ性調合香料の例をホす寸。 まず,抗菌性調合香料だが, No. 1451 は leafy, green, freshな香り, No. 1452 は pine, herbal, freshな香 りである。ハロー試験法のデータ（Table-16）だ
けであるが，抗莎性在小している。次は防力ビ性 泵料の例だが，No. $5(022$ は citrus, rose の秀り，No. 5023 は spicy, rose の秀り, No. 5024 は green, floral,

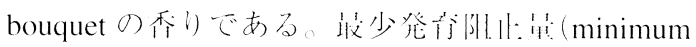
inhibitory amount : MIA) のデータをTable-17に

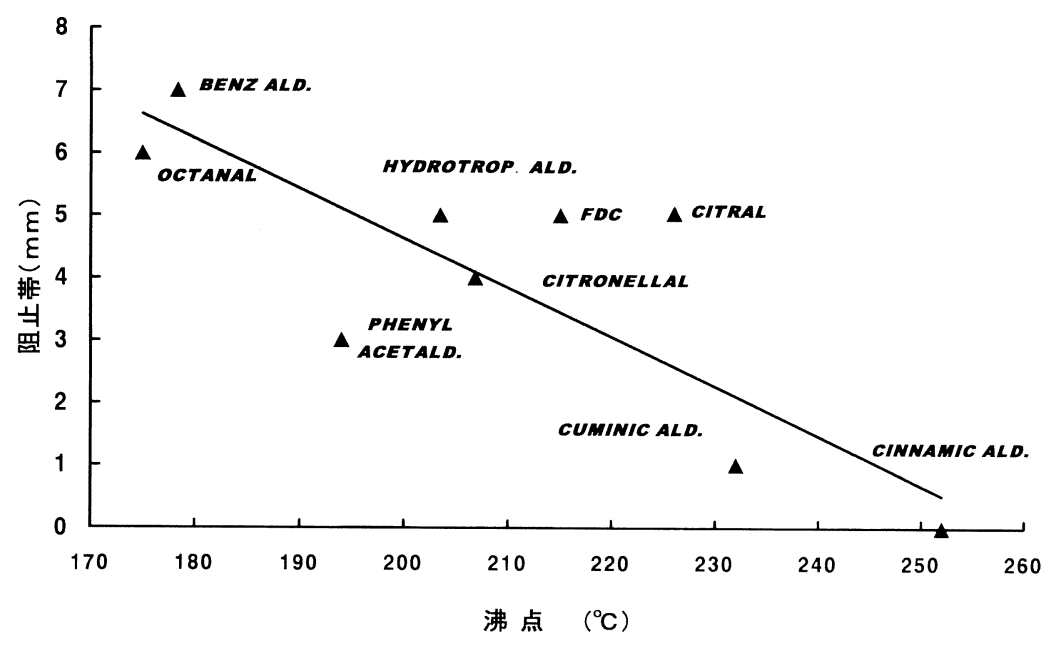

Fig. -14 Relation between boiling point and antibacterial activity.

Table-15 Safety and stability matters of antimicrobial perfume.

\begin{tabular}{|c|c|c|c|}
\hline & 父全吽 & 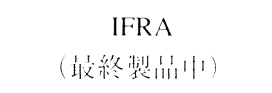 & 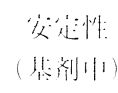 \\
\hline Cassia oil & 弱い感作性 & $0.2 \%$ 以卜 & 变们 人 \\
\hline Cinnamon bark & 感作吽: & $0.2 \%$ 以上 & 变仙人 \\
\hline Cumin oil & 光毒:性: & $0.4 \%$ 以下 & \\
\hline Oakmoss ext. & 感作性 & $0.5 \%$ 以ト & 变任人 \\
\hline Rue oil & 光青:性: & $0.78 \%$ 以ト & \\
\hline Cinnamic ald. & 感作性 & クエンチング & 变仙 人 \\
\hline Citral & 感作性: & クエンチング & 多们 \\
\hline Isoeugenol & 感作性 & $0.02 \%(0.1 \%)$ 以ト & 忿腋 \\
\hline Perilla ald. & 妈い感作性 & $0.1 \%(0.2 \%)$ 以卜 & \\
\hline
\end{tabular}

Table-16 Antibacterial compound perfume ( $\mathrm{mm})$.

\begin{tabular}{lccccc}
\hline & \multicolumn{2}{c}{ B. subtilis } & & \multicolumn{2}{c}{ E. coli } \\
\cline { 2 - 3 } \cline { 5 - 6 } & $\begin{array}{c}\text { Direct } \\
\text { contact }\end{array}$ & Vapor & & Direct & Vapor \\
& state & & contact & state \\
\hline No.1451 & $80<$ & $80<$ & & 24 & 0 \\
No.1452 & 60 & 60 & & 60 & 60 \\
\hline フェノール $50 \%$ & 27 & & & 28 & \\
\hline
\end{tabular}


少古。

\section{7. 最近の問題}

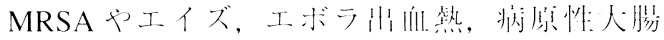

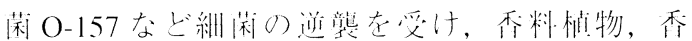
料の仿隹が㞦さ扎てもよい。MRSAに刘し ては, peppermint oil, citral, citronellal, $l$-perilla aldehyde, F.D.C., thymol, hinokithiol, tetrahydrolinal$\mathrm{ool}^{3 \mathrm{~N}}$, クローブ, オールスパイス, シナモン, ナッツメグ，マジョうム，ローズマリー，七ージ 抽期物 が们效である。O-157には，もずく，納

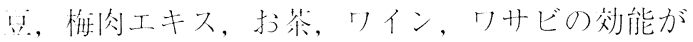

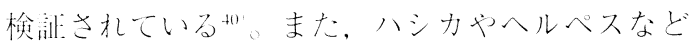
の佰膜ウイルスに刘して, pinene類, citral, tetrahydrolinalool などが们效である゙、いずれにせよ，

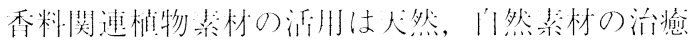

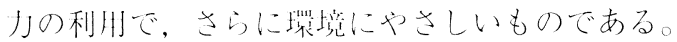
最近，洗浄剂などのトイレタリ一衡肾や等香剂な

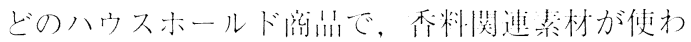

れた除菌製品が注目されている。

\section{3. 香料および香料関連植物の抗酸化性}

\section{1. 香料植物からみた抗酸化性}

再び，Blakeway の文献から7”。植物では，响木 の)が抗酸化性がある（Fig.-15）。これは喬木の 方が 20 年から数百年，あるいはそれ以上に生育 期間が圭く，それだけ抗酸化性がなければならな いからである。

抗酸化性のよい精油は，喬木でいうと，葉から， cedar leaf, bay，花加 clove，果実加， pimento， nutmeg (当然，香辛料系が多い)，樹脂から， peru balsam, tolu balsam, 幹部から, virginian cedar, sandalwoodなどである。草本でいうと，全植物の thyme white, thyme, red, 花からの rosemaryなど である。とくに，長期のデータからいうと， clove， pimento, thymeがよい。

先に，香辛料の抗酸化性に触れたが，Fig. -16

Table-17 MIA of antifungal compound perfume $(\mu \mathrm{L})$.

\begin{tabular}{|c|c|c|c|c|c|c|c|}
\hline & \multicolumn{7}{|c|}{ 试 験 莉 } \\
\hline & $\mathrm{AN}$ & $\mathrm{PC}$ & $\mathrm{PF}$ & RJ & MS & $\mathrm{CC}$ & GV \\
\hline No. 5022 & $<2$ & $<2$ & 5 & $<2$ & $<2$ & $<2$ & 5 \\
\hline No. $5(1) 23$ & 5 & $<2$ & 5 & 20 & 5 & $<2$ & 5 \\
\hline No. $5(1) 24$ & 5 & 5 & 10 & 10 & $<2$ & $<2$ & 10 \\
\hline
\end{tabular}

AN : Aspergillus niger, PC : Penicillium citrium, PF : Penicillium funiculosum, RJ : Rhizopus jaranicus, MS:Mucor spinescens, CC:Cladosporium cladosporioides, GV : Gliocladium virens, CG : Chatomium globosum.

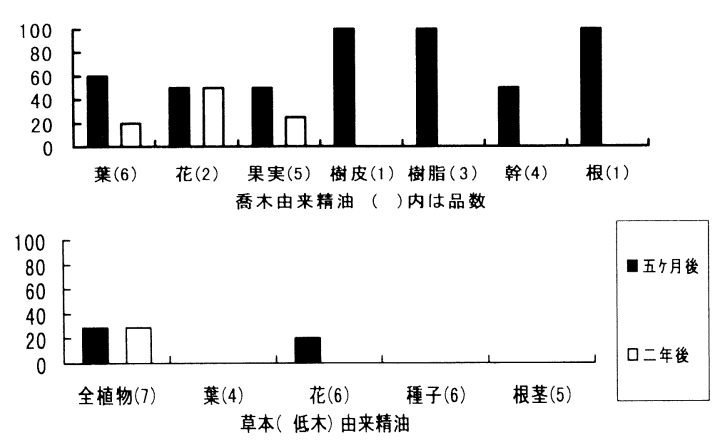

Fig. -15 Percentage of essential oils showing antioxidant activity $(\%)$ in trees and shrubs.

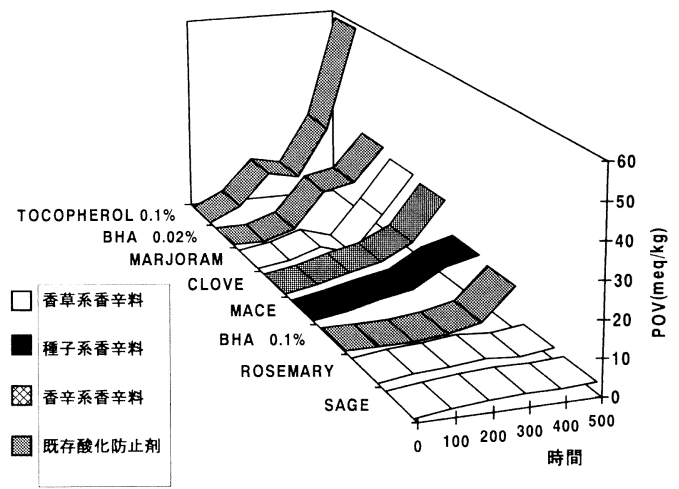

Fig. -16 Antioxidant activity of spices $(0.1 \%$ in lard). 
は香辛料粉末の酸化防止機能のデータである ${ }^{+21 。}$ 葉茎部位からの薬草系香辛料 (ハーブスパイス) sage, rosemary の抗酸化性が強く, thyme, marjoram, oregano が続く。香辛料系香辛料（スパイシース パイス）は clove, ginger 以外は効果がない。種子 系香辛料では mace のみである。

香料素材の抗酸化については Table-18に示 す43) -46)。

近年，活性酸素消去に関する関心が高まってお り，スーパーオキシド，ヒドロキシラジカル，一 重項酸素等の消去が注目されている。それらの活 性酸素消去を含めた抗酸化についての香料関連植 物抽出物のまとめを, Table-19, 20 に示す47)-781。 また, 香料関連植物抽出物の SOD 様活性の 1 例 を Fig. -17 に示す。

\section{4. 非言語（ノンバーバル）コミュニケー ション手段としての香り}

「人間のコミュニケーションにおける言葉の役 割は 7\%にすぎず，伝達のほとんどは非言語的な 手段による」といわれている ${ }^{79)}$ 。非言語的な（ノ ンバーバル)コミュニケーション手段とは, Table21 に示すが79), (1) 身体的な特徵, (2) 顔の表情, (3) 視線行動, (4)手振りと身振り, (5) 身体接触, (6) 匂い, (7)空間や距離, (8)声の質, 大きさ, 高 低, 話す速度と声の区切り, 話し方などのパラ言
活管である。そのほか，通婂，装身少，服装，髮 型，化粠，沈黙などを㞦える坋命がある。

さて，本題の饪（秀り）であるが，相丁:の创 いによって，よいにせよ照いにせよ，印象が右右 される。泪い朼いは，とくに本能的である。体奥 や，空港を降り舜ったときの罢员に対しては，本

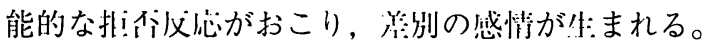
それは，咱兴の本筫である。したがって，创いや 香りは䦌造いなく非、涪コミュニケーション乎段 である。

香りがコミュニケーション丁段だということは, 香りが何らかのメッセージを送ることであり，大 胆にいえば，「㔻りは、㪙だ」ということである。 能崎はすでに，昭利 49 华発行の「监界の香水」 のなかで，化いがメーキャップと闬棣に社会的な け衙活動であると指摘している"00。

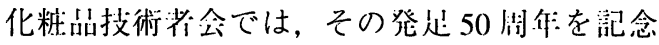
して施念誌を発衍したが,「21 世:糺へのメッセー ジ」として，内面恣をとりあげている。これは 21 世糺への感吽の閌题であるが, 非、活コミュニケ

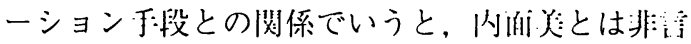

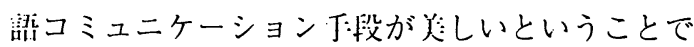

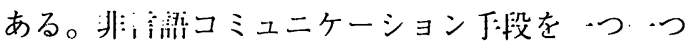
見ていく。

会った瞬阙にまず川に入ってくるのは身体的特 徴である。兑人が得をすることはそうなのだが，

Table-18 Antioxidant activity of perfume.

\begin{tabular}{|c|c|c|}
\hline 化合物 & 火然精洲と抗酸化の特徵 & 文峒 \\
\hline Eugenol & Clove, allspice, cinnamon leaf, mace, nutmeg & 43) \\
\hline Isoeugenol & Mace, nutmeg & 43) \\
\hline Thymol & Thyme, allspice & $4.3)$ \\
\hline Anethol & Anise seed & 43) \\
\hline Methyl chavicol & Basil, tarragon & 43) \\
\hline Cinnamic aldehyde & Cinnamon bark & 43) \\
\hline Vanillin & Vanilla & 43) \\
\hline Shogaol & Ginger & 43) \\
\hline Limonene & Citrus oil & 43) \\
\hline Citral & Lemon & 43) \\
\hline Linalyl acetate & 加熱大豆油の酸化防j少: & 44) \\
\hline Vanillin とその配糖体 & 生体内の活性酸素捕捉・游忘 & 45) \\
\hline Eugenol 誘導体 & $\begin{array}{l}\text { Eugenol はスーパーオキシドと OH ラジカル捕捉 } \\
\text { Dieugenol はスーパーオキシドの捕起能あり }\end{array}$ & 46) \\
\hline
\end{tabular}


Table-19 Antioxidant activity of perfume-related plant extracts (1).

\begin{tabular}{|c|c|c|c|}
\hline 惦物多 & 们效成分 & 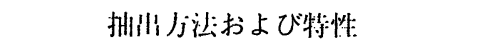 & 文献 \\
\hline $\begin{array}{l}\text { ローズミリ } \\
\text {-抽性物 }\end{array}$ & 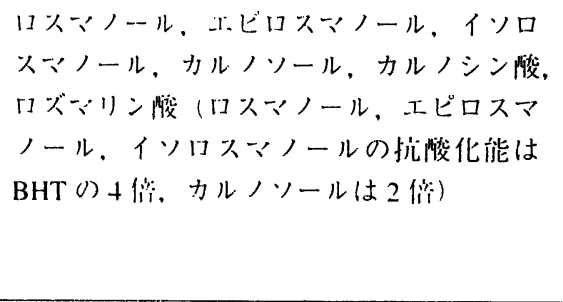 & 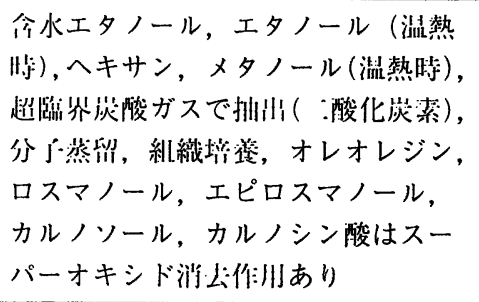 & 47) 52) \\
\hline 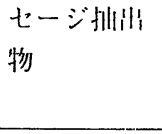 & 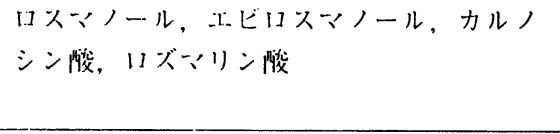 & 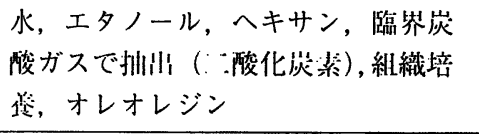 & $\begin{array}{l}47), 48), \\
50 \sim 52)\end{array}$ \\
\hline シソ扠性 & 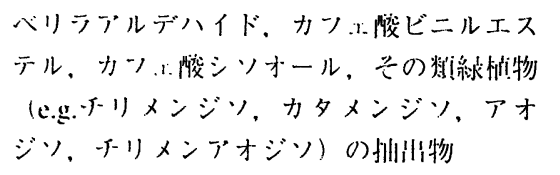 & 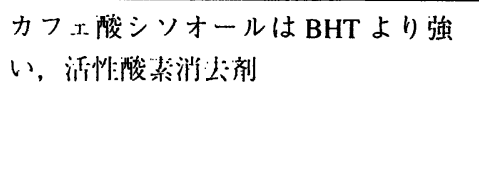 & $53), 54)$ \\
\hline タイム抽il & 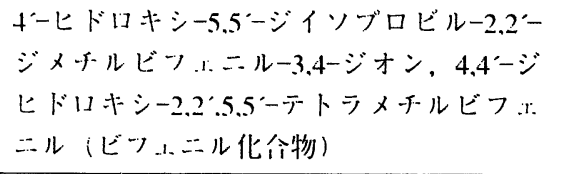 & 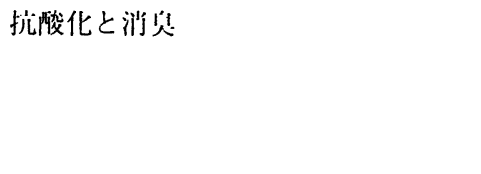 & $55), 56)$ \\
\hline $\begin{array}{l}\text { クローブfill } \\
\text { 川物 }\end{array}$ & オイゲノール，デハイドロジオイゲノール & 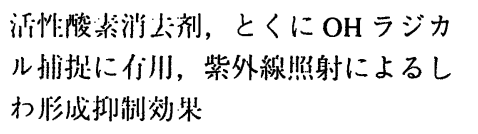 & $57), 58)$ \\
\hline 甽滥化苓物 & $\begin{array}{l}\text { コニソッリルベンゾルイト，オイゲノール， } \\
\text { デヒドロジイソオイゲノール，イソオイゲ } \\
\text { ノール }\end{array}$ & 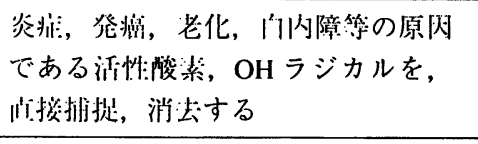 & 59) \\
\hline " & デヒドロジクレィソール & 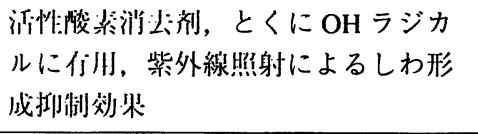 & 60) \\
\hline $\begin{array}{l}\text { オレガノ扠 } \\
\text { 川物 }\end{array}$ & 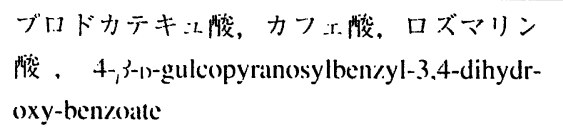 & エタノール, 水蒸矧蒸留 & $48), 61)$ \\
\hline 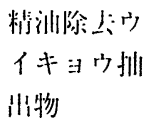 & +-()-(イ-1)-ダルニシルシナビルアルコール & 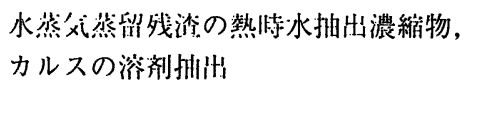 & $\begin{array}{l}\text { 57), 62), } \\
63)\end{array}$ \\
\hline
\end{tabular}

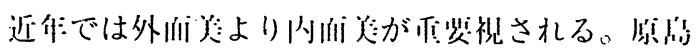

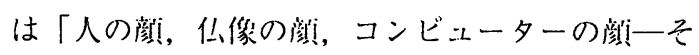

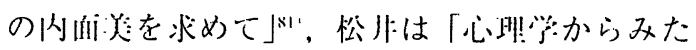

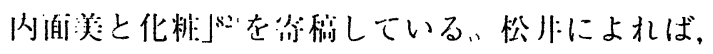

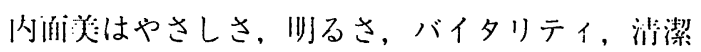
さなどであるとしている、

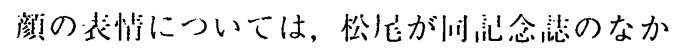

で3.1 「人の印象は 6 秒で決まるという。この短 い将䦌に，人に好印象を与えるのは言葉でなく笑 顔である」と述べている。笑顔の威力は言葉をは るかに淩ぐのである。6秒では, 言葉で一言か二 けである。適切であればよいが, 適切でなければ 湖解を招く。弁解すれば,するほどよけい悪くな る。それとは逆に笑顔はすべてを包み込むのであ 
Table-20 Antioxidant activity of perfume-related plant extracts (2).

\begin{tabular}{|c|c|c|c|}
\hline 植物名 & 有効成分 & 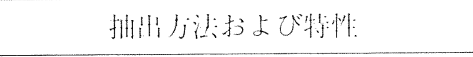 & 文献 \\
\hline $\begin{array}{l}\text { コショウ抽 } \\
\text { 出物 }\end{array}$ & $\begin{array}{l}\text { フェルペリン, カプサイシノイド配糖体, } \\
\text { アミド化合物 }\end{array}$ & 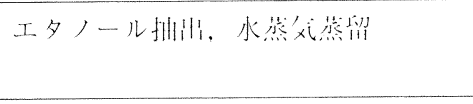 & 47), 57) \\
\hline $\begin{array}{l}\text { ジンジャー } \\
\text { 抽出物 }\end{array}$ & $\begin{array}{l}\text { ジンゲロン, ジンゲロール，ヘキサヒドロ } \\
\text { クルクミン, ショウガオール， ジアリール } \\
\text { ヘプタノイド }\end{array}$ & & $64), 65)$ \\
\hline $\begin{array}{l}\text { セイヨウワ } \\
\text { サビ抽出物 }\end{array}$ & イソチオシアネート & 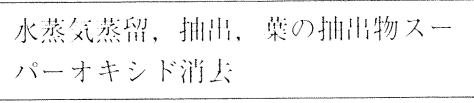 & 66) \\
\hline $\begin{array}{l}\text { ゴマ油抽出 } \\
\text { 物 }\end{array}$ & $\begin{array}{l}\text { セサモリン，セサモール，七サモリノール， } \\
\text { セサミノール，カフエ酸配糖体，リグナン } \\
\text { 配糖体 }\end{array}$ & 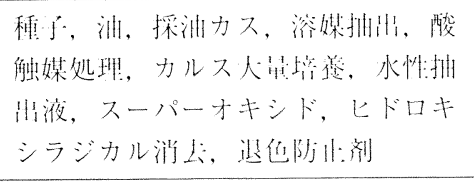 & $\begin{array}{l}\text { 47), 57) } \\
67)-71)\end{array}$ \\
\hline $\begin{array}{l}\text { トウガラシ } \\
\text { 抽出物 }\end{array}$ & $\begin{array}{l}\text { カプサイシン, カプサイシノール, カプサ } \\
\text { イシノイド }\end{array}$ & & 72), 73) \\
\hline $\begin{array}{l}\text { ユーカリ樹 } \\
\text { リーフワッ } \\
\text { クス }\end{array}$ & $\begin{array}{l}n \text {-トリトリアコンタンー16,18-ジオン } 4^{-} \\
\text {ヒドロキシトリトリアコタン-16,18-ジオ } \\
\text { ン }\end{array}$ & 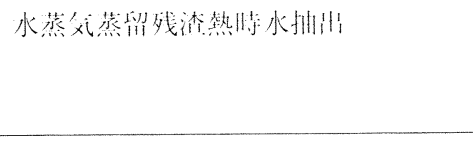 & $68)-74)$ \\
\hline 花弁抽出物 & $\begin{array}{l}\text { バラ, ヤエサクラ, モモ, ウメなどの花弃。 } \\
\text { クエルセチン配糖体 }\end{array}$ & 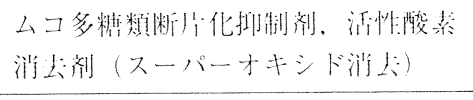 & $75), 76)$ \\
\hline $\begin{array}{l}\text { シトラスオ } \\
\text { イル (レモ } \\
\text { ン,ライム) }\end{array}$ & $\begin{array}{l}\text { 5-ヒドロキシー7-メトキシー8-ゲラニルクマ } \\
\text { リン，5-ヒドロキシ-8-ゲラニルソラーレ } \\
\text { ン }\end{array}$ & & 77) \\
\hline $\begin{array}{l}\text { グレープフ } \\
\text { ルーツオイ } \\
\text { ル }\end{array}$ & $\begin{array}{l}\text { Bergaptol, 7-methoxy-8 (2,3-dihydroxy iso- } \\
\text { penthyl) coumarin }\end{array}$ & $\begin{array}{l}\text { ラジカル消ム, スーバーオキシド消 } \\
\text { 去 }\end{array}$ & 78) \\
\hline
\end{tabular}

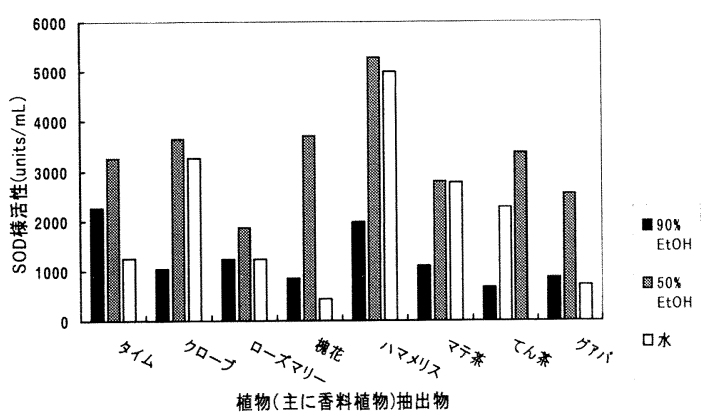

Fig. -17 SOD like activity of perfume related plant extracts.

る。すべてを溶かし込む。それができる笑顔はス マイル (smile) だけである。ラフ (laugh) では
Table-21 Non-verbal communication means.

(1) 身体的な特徽 (2) 谪の余情

(3) 視線行動 (4) F:拢り上身拢り

(5) 身体提触 (6) 化い

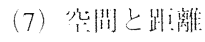

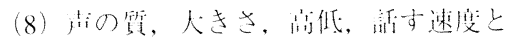
,

ない。ラフは落酎などを胿いて笑う受動的な笑い だが，スマイルはその人の特き様がにじみ出る， 自己表現の笑いである。H本人の顔の表情は能面 のようで，心のなかをなかなか明らかにしない。 松尾はこれからの同際化時代に借えて，日本人の 笑顔の遅机を取り疾すべく，スマイルエクササイ 
ズを提䀠している。

視線行動は，间仙念沾で，け川がシェルドレイ

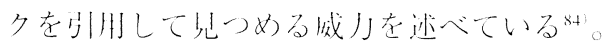

非、活コミュニケーション丁段老川本と网際社: 会とで比糘したものが、Table-23である。乎体 的特徽はよいとして，摘の衣悄は，松もが先に触

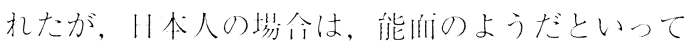

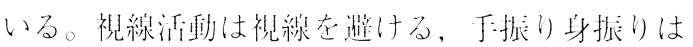
控えめ，身体捽触は少ない，古の大きさ，活しおj は控えめ，孙(㔻り）は保得意(控えめ)，とい

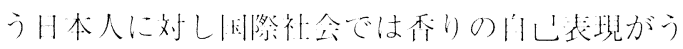
まい。

H本はこのままでいいのか。川本は目際社会の 貝になっうとしている。ということは、コミュ ニケーション丁段も收摔せ权ばということである。

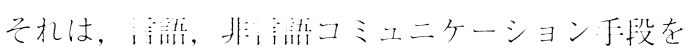
能動的にするということで，㔻り，化いについて も能動的になるということである。

先の能崎の淪文が载つている特集木は奀水文化 が日本でなかなか忧づかないので们とかしようと

Table-22 Features of non-verbal communication means.

\begin{tabular}{|c|c|}
\hline 身休的な特微 & 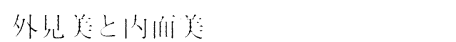 \\
\hline 顔の就情 & 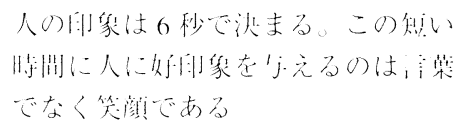 \\
\hline 視線行動 & 呒こ上の威」」 \\
\hline 沙 い & 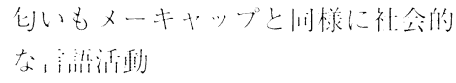 \\
\hline
\end{tabular}

Table-23 Japan and the West.

\begin{tabular}{|c|c|c|}
\hline & 11 & 炊米消|⿴囗十 \\
\hline 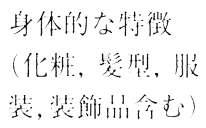 & 適以 & 適以 \\
\hline 顔の衣情 & 能间のよう & 笑颜がこばれる \\
\hline 视緗行動 & 视線が熦けがた & 古視 \\
\hline 手:振り上奴报引 & 控之め & オーバーぎみ \\
\hline 身休捽触 & 少ない & 多い \\
\hline 突䦌上趾脑倠 & 敞札ている & 近い \\
\hline 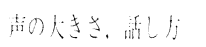 & 控之况 & 溧発 \\
\hline 屾（秫门） & 不得甞 & 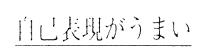 \\
\hline
\end{tabular}

いうのであるが，このとき（昭和 49 年）と現在 で, 日本の香水文化の状況が大して变わらない状 沉に，驚きとともに，無念さを禁じ得ない。

欧米では，自己表現として使う香水，コロンは， 6 秒の中で，いい意味でも，悪い意味でも相手に 影響を与える。日本では, そ机は希薄である。

香水文化が日本でなかなか根づかないことに関 して，上前は「読むクスリ」 ${ }^{85}$ で，その理由を挨 拶のしかた，すなわち拉辞儀と抱擁の差としてと らえている。挨拶のしかたも，欧米では，抱擁で あるので，它いを気にしない訳にはいかない。日 本は，㧍辞儀なので距離が離れており，匂いを気 にしなくてよい。香水も必要性が少ないわけであ る。日本文化では, 手振りと身振り, 身体接触は 少ない。

山本はこのままでいいのか。括辞儀が抱擁にな ることはないが, すでに, 香りの自己表現は若い 人や国祭人から始まっている。21 世紀のグロー バル化時代に備えて, 積極的な方向, 受身から能 動に切り替える。当然，切り替わると思う。匂い (香り) 環境も改善されねばならない。

「香りは言葉だ」というところにもどる。通常 「化いは言葉だ」というと, それは動物に対する フェロモンのことをさす。動物に対するフェロモ ンのことを主に扱っている $\mathrm{R} ・$ バートンの「ニオ イの世界」我の原題は The Language of Smell で, 文字どおり「㫐いの言葉」である。「香りは言葉 だ」というと人間に対するフェロモンということ になるが，今回はその分野には入っていかない。

今回は香りと人間との出会いの観点, すなわち 否りによる出会いのメッセージの観点からとらえ ていく。香りによる出会いのメッセージを熊井の 文章でみると, 信州出身の彼女は沈丁花の香りに ついてこう書いている871。

「信州の春は，もどかしくなるほど歩みが遅い。 ……だが或る日，風のに拉いが変わる。….. その中に沈丁花の香りが混じっていたら, 本 当の春である。沈丁花の香りは, すっと脳髄 に響くようでシャープで，底に官能的な甘さ をひめている。……少女の頃, 冬になると体 調を崩し, 気分までが落ち达んでいた私に 
とって，沈丁花は特别の花だった。禀とした 香りを聞くと，一僢，心が躍り，勇父でけら 机る」

沈丁花の香りから熊井がどういう香りのメッ七 ージ（サイン，コトバ）を受けたかよくわかるの である。さらに，別の個所で「花には様々な鬽力 があるが，私の場命一番ひかれるのは番りである。 香りは, 花の声のように思われる。花は皆, あら ゆる国の言葉を語る」といっている。

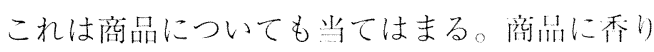
をつけるということは，商品が声を発するという ことで，製品に香りを付けないということは牒を 失うということである。これは㒀品の顔を失うの と同じである。香料使用の主目的は最終墑品の香 り付けで，それは商品の美的俩值を高め，敵品の 魅力を高めることである。香料は香りをもたらす ものという当たり前のことであるが，これが，先 に述べたが香料の最大の特性である。この占が令 回のメインの主張ポイントである。

香料の機能面が重視される昨令，ややもすると， それは，香るということ以外の機能の追求となり かねないので，香料の命は香りであることを临浔 識したいためである。化粰品では微香性, 血秃料 の時代が長かったが,ここにきて，香りのよい淮 品が売れる，すなわち香りが㒀の南や颜になっ ていた時代が再びやってきているとの徵候を感じ る。とくに，トイレタリー衲品の香りはそうであ る。その意味で, 21 世紀は香りの時代を答さ せるのである。

そのためには，先に述べた 21 世糺のグローバ ル化時代に備えた匂い（香り）環境の積楎的う们， 受身から能動への切り替えのほかに, 萃荣学侨 するプロセスが重要である。小さな子どもが文字 どおりの言葉を覚えるのと同じように，香りの) i 葉を覚えやすい環境作りが重要である。广供の间 りに，たくさんの香りがあり，多くのメッセージ をうけとる環境を作っていきたいものである。

\section{5.おわりに}

微生物の逆襲を受けたり，日光の帘，酸素の: が明らかになってきた昨今, よりナチュラルとい

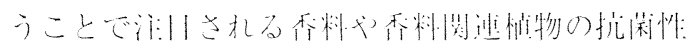

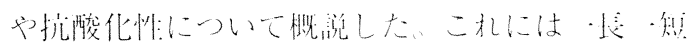

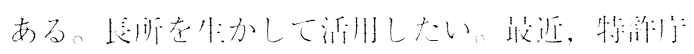

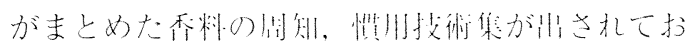

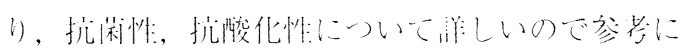
されたい。㔻料の箱㳉におたのての機能性につ いても大いに㚆考になる。

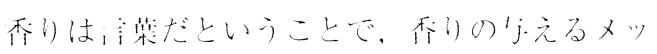

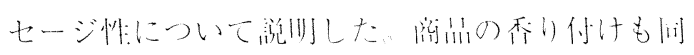

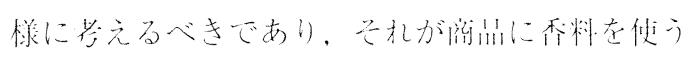
第 のの泪的である。

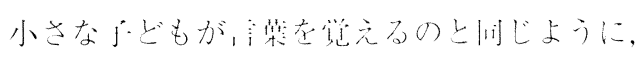
ケどもの清りにたくさんの秀りがあり、多くのメ

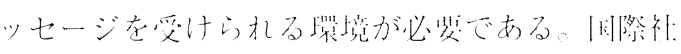

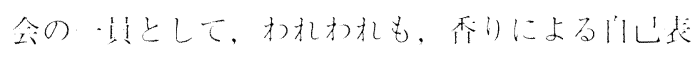
悓老身につけたいものである。

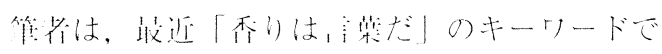

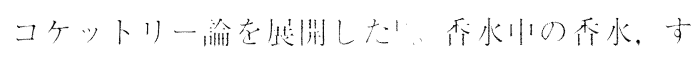

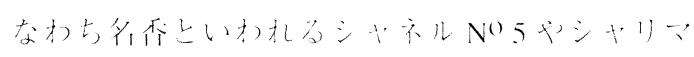

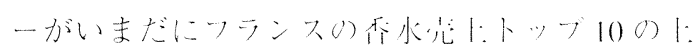

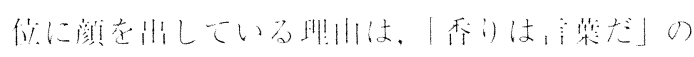
キーリードで解けるこ上在师的かにした。多㔻は

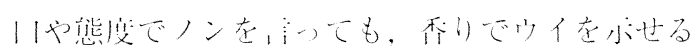

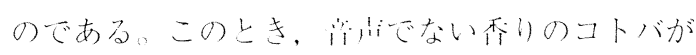
発敝さ机る。こ机ぶ、机くコケットリーである ジャン・ポール・ゲランの、菜ではないが、㔻水

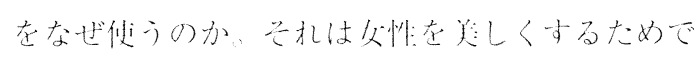
あるっフレグランス老使う究懒の川的が、この知 い、箱に皆的机ている

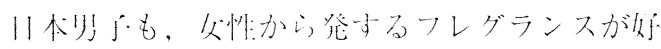
ましいと誌ったら，长しい上彼众に佉えても的い たい。そこから，㔻りの、菜文化がス夕一トする のである。少从老人札筷え机ば，归性フレグラン

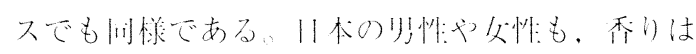

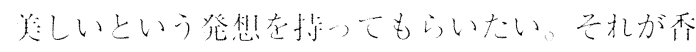

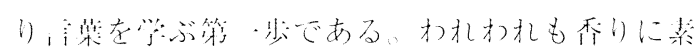
脽に感㽖できる你作でありたい

\section{引用文献}

1) 浅越 H. Hasegawa Lett. 8. 16-21 (1998)

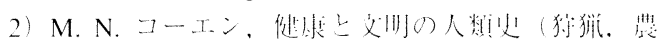




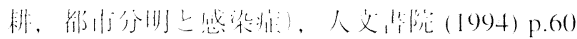

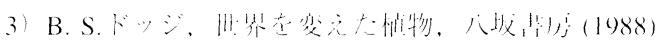
P. 57

4) F. Rosenganten. Jr.. The Book of Spices. Livingston Publishing Co. (1969) p.51. 74

5) $11195 \mathrm{j}$ 等 (1981)

6) Illsto 16 J. Antibact. Antifung. Agents, 10, 115$128(1981)$

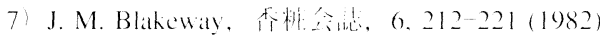

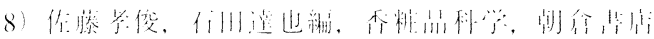
(1997) p. 45

9) J. C. Maruzcellit, M. B. Lichtenstein, J. Am. Pharm. Assoc.. 45. 378-381 (1956)

10) J. C. Marurcella. N. A. Sicurella. J. Am. Pharm. Assoc. $+49.692-69+(1960)$

11 J. C. Marusella, L. Liguori. J. Am. Pharm. Assoc., +7. 25()$-2.5+(1958)$

12 J. C. Maruredla. S.P.C. 33. $83.5-8.37(1960)$

$13)$ J. A. Morris, A. Khettry. E. W. Scit/, J. Am. Oil Chem. Soc.. 56, 595-60)3(1979)

If K. Salwano, T. Sato, R. Hattori, J. Soc. Cosmet. Chem. Jpn.. 27, 227-241(1993)

15 T. Yoshikawal. S. Miharal. J. Soc. Cosmet. Chem. Jpn. 21.104-110(1987)

16. S. Gechou, J. Antibact. Antifung. Agents, 19, 329 $3.3+(1991)$

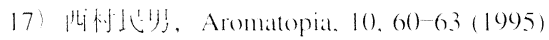

18 J. C. Marusella, E. Bramnick, S.P.C. 34. 743-746 (1961)

19) J. C. Maruzella. M. M. Garofialo. J. S. Chiaramonte. Am. Perfum., 2. 35-38 (1961)

20) J. C. Marusella. J. S. Chiaramonte. M. M. Garofalo, J. Pharm. Sci.. 50. 665-668 (1901)

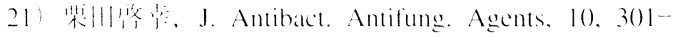
$308(1982)$

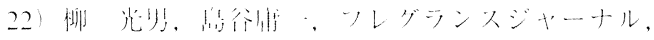
$17(2) .14-23(1989)$

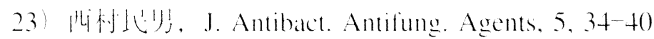
(1977)

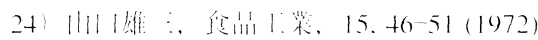

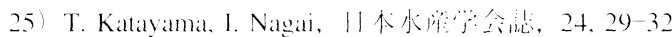
$(1960)$

26) S. Gochou. J. Antibiat. Antifung. Agents, 20. $585-$ 589 (1992)

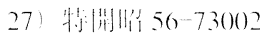

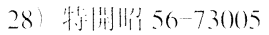

29) 特湔椨 62-111675
30) 特㴸怕 4-21606

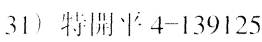

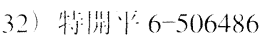

33) 特湔中 $8-511517$

34) 特公中 3-77161

35)还少顺犬，フレグランスジャーナル，26(12)，122128 (1998)

36) S. Gochou, J. Antibact. Antifung. Agents, 19, 511$515(1991)$

37) 㷊H利1 ⿺ J. Soc. Cosmet. Chem. Jpn., 31, 124-137 (1997)

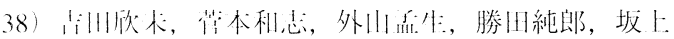

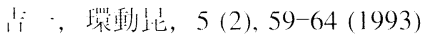

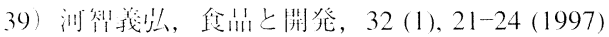

40) Food Style 21, 1 (5), 91-94 (1997)

41) 特洴中' 5-306217

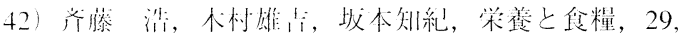
404-408 (1976)

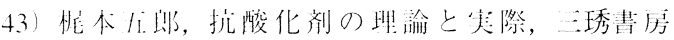
(1984) p.3-25

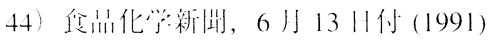

$45)$ J. Burri, M. Graf, P. Lambelet, J. Loliger, J. Sci. Food Agric., 48 (1), 49-56 (1989)

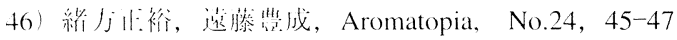
(1997)

47) 1行还: , 㔻料, No.157, 41-46 (1988)

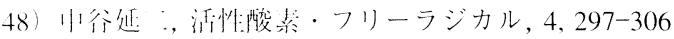
(1993)

49)八木光，原惲行，フレグランスジャーナル， 22 (11), 59-65 (1994)

50) 特洲中.1-108952

51）特溜情3-9984

52）特洲中.4-247054

53) 多胡全, Aromatopia, No.24, 48-49 (1997)

54)特淉中. 7-252161

55) 特洲火.2-160737

56) 特洲中'4-120038

57）人扴則人，フレグランスジャーナル， 25 (4)，8895 (1997)

58) 特阙\% 3-227938

59) 特阙怕 3-263481

60) M. Sada, T. Ikemoto, H. Nakatsugawa, Proc. 3rd ASCS, 125-129 (1997)

61) 特㴊师 62-26293

62) 特洞中: $3-140394$

6.3) 特洲以 5- 171144

64) 汌犁峩出, FFI ジャーナル，163, 44-55 (1995)

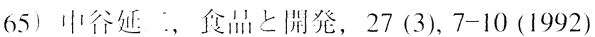




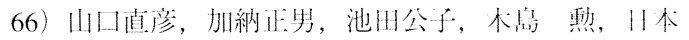
食品工業学会誌，31，114-119 (1984)

67）大澤俊彦，フードケミカル，34, 65-69 (1988)

68）大澤俊楌, FFI ジャーナル, 163, 19-29 (1995)

69）特開昭 58-132076

70) 特開昭 62-581

71) 特開平 4-66591

72）中谷延- -, 香料, No.184, 97-103 (1994)

73) 特開平 5-86086

74) 特開平 6-172184

75）末次一博, フレグランスジャーナル，25 (4), 7580 (1997)

76) 特開平 7-309770

77）平本忠浩，高砂時報，126，13-22 (1997)

78) 所一陔, Aromatopia, 24, 42-44 (1997)

79) 稗島一郎, 宫葉の心理, 北樹出版 (1994) p.44-55

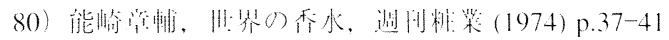

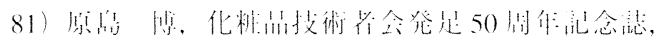
24-31 (1997)

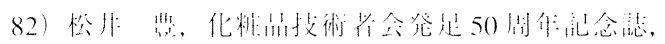
$32-39(1997)$

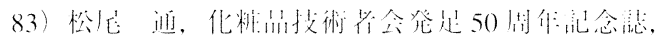
40-47 (1997)

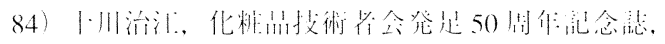
$18-23(1997)$

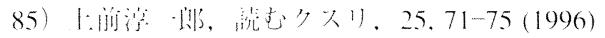

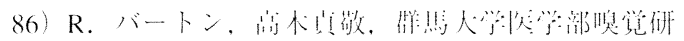

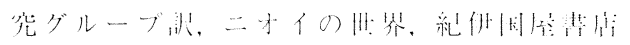
(1978)

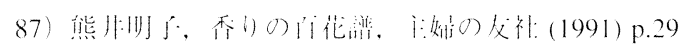

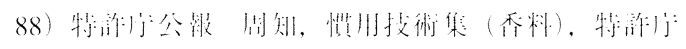
(1999)

\title{
Fragrances and Their Special Properties - Antibacterial and Antioxidant Activity of Fragrance Materials and Aromas Used as a Tool of Non-Verbal Communication - *
}

\author{
Toru Asakoshi \\ Fragrance Institute, T. Hasegawa Co.. Ltd. ${ }^{* *}$
}

\begin{abstract}
In general, odors are everything one can sense while aromas are something which will give comfort and relaxation. Whether particular aroma is said to be good or bad will largely depends on ones own personal experiences or cultural background. Fragrance materials are narrowly defined as products handled by the fragrance industry, while more broadly, they are everything which will bring about aromas. Primary objective of the use of fragrance materials in the final products is of course to help enhance an artistic value, attractiveness or comfortness of such products. This is basically what the fragrances are for. In addition to these, they also possess many other functions. Of these, I will discuss the antibacterial and antioxidantive aspects which are said to be two of the most representative functions. As we become more keenly aware now that we are being exposed to the counterattack by microorganisms and to the harmful sunlight or being damaged by the oxygen, the studies on these characteristics are getting attention among researchers. As the same time. I will discuss also the role of aromas in terms of non-verbal communication as viewed in a cultural context. It should be reminded once again that the very basic and essential function of fragrance materials is after all to give aromas.
\end{abstract}

Key words : Antibacterial activity, antifungal activity. antioxidant activity. non-ecrbal communication means. fragrance, fragrance material, aromas, essential oil. aromachemical. perfume, perfume-related plant extract. trees. shrubs 